NBER WORKING PAPER SERIES

\title{
GETTING BENEATH THE VEIL OF EFFECTIVE SCHOOLS: EVIDENCE FROM NEW YORK CITY
}

\author{
Will Dobbie \\ Roland G. Fryer, Jr \\ Working Paper 17632 \\ http://www.nber.org/papers/w17632
NATIONAL BUREAU OF ECONOMIC RESEARCH
1050 Massachusetts Avenue
Cambridge, MA 02138
December 2011

We give special thanks to Seth Andrews and William Packer of Democracy Prep Charter School, Michael Goldstein of the MATCH charter school, and James Merriman and Myrah Murrell from the New York City Charter School Center for invaluable assistance in collecting the data necessary for this project. We are grateful to our colleagues Michael Greenstone, Larry Katz, and Steven Levitt for helpful comments and suggestions. Sara D'Alessandro, Abhirup Das, Ryan Fagan, Blake Heller, Daniel Lee, Sue Lin, George Marshall, Sameer Sampat, and Allison Sikora provided exceptional project management and research assistance. Financial support was provided by the John and Laura Arnold Foundation, the Broad Foundation, and the Fisher Foundation. Correspondence can be addressed to the authors by e-mail: dobbie@fas.harvard.edu [Dobbie] or rfryer@fas.harvard.edu [Fryer]. The usual caveat applies. The views expressed herein are those of the authors and do not necessarily reflect the views of the National Bureau of Economic Research.

NBER working papers are circulated for discussion and comment purposes. They have not been peerreviewed or been subject to the review by the NBER Board of Directors that accompanies official NBER publications.

(C) 2011 by Will Dobbie and Roland G. Fryer, Jr. All rights reserved. Short sections of text, not to exceed two paragraphs, may be quoted without explicit permission provided that full credit, including $\odot$ notice, is given to the source. 
Getting Beneath the Veil of Effective Schools: Evidence from New York City

Will Dobbie and Roland G. Fryer, Jr

NBER Working Paper No. 17632

December 2011

JEL No. I20,J10,J24

\begin{abstract}
$\underline{\text { ABSTRACT }}$
Charter schools were developed, in part, to serve as an R\&D engine for traditional public schools, resulting in a wide variety of school strategies and outcomes. In this paper, we collect unparalleled data on the inner-workings of 35 charter schools and correlate these data with credible estimates of each school's effectiveness. We find that traditionally collected input measures -- class size, per pupil expenditure, the fraction of teachers with no certification, and the fraction of teachers with an advanced degree -- are not correlated with school effectiveness. In stark contrast, we show that an index of five policies suggested by over forty years of qualitative research -- frequent teacher feedback, the use of data to guide instruction, high-dosage tutoring, increased instructional time, and high expectations -- explains approximately 50 percent of the variation in school effectiveness. Our results are robust to controls for three alternative theories of schooling: a model emphasizing the provision of wrap-around services, a model focused on teacher selection and retention, and the "No Excuses" model of education. We conclude by showing that our index provides similar results in a separate sample of charter schools.
\end{abstract}

Will Dobbie

Education Innovation Laboratory

Harvard University

44 Brattle Street, 5th Floor

Cambridge, MA 02138

dobbie@fas.harvard.edu

Roland G. Fryer, Jr

Department of Economics

Harvard University

Littauer Center 208

Cambridge, MA 02138

and NBER

rfryer@fas.harvard.edu

An online appendix is available at:

http://www.nber.org/data-appendix/w17632 


\section{Introduction}

Improving the efficiency of public education in America is of great importance. The United States spends $\$ 10,768$ per pupil on primary and secondary education, ranking it fourth among OECD countries (Aud et al. 2011). Yet, among these same countries, American fifteen year-olds rank twenty-fifth in math achievement, seventeenth in science, and twelfth in reading (Fleischman 2010). Traditionally, there have been two approaches to increasing educational efficiency: (1) expand the scope of available educational options in the hope that the market will drive out ineffective schools, or (2) directly manipulate inputs to the educational production function.

Evidence on the efficacy of both approaches is mixed. Market-based reforms such as school choice or school vouchers have, at best, a modest impact on student achievement (Rouse 1998, Ladd 2002, Krueger and Zhu 2004, Cullen, Jacob, Levitt 2005, 2006, Hastings, Kane, and Staiger 2006, Wolf et al. 2010, Belfield and Levin 2002, Hsieh and Urquiola 2006, Card, Dooley, and Payne 2010, Winters forthcoming). This suggests that competition alone is unlikely to significantly increase the efficiency of the public school system.

Similarly, efforts to manipulate key educational inputs have been hampered by an inability to identify school inputs that predict student achievement (Hanushek 1997). ${ }^{1}$ This is due, at least in part, to a paucity of detailed data on the strategies and operations of schools, little variability in potentially important inputs (e.g. instructional time), and the use of non-causal estimates of school effectiveness. For instance, the vast majority of quantitative analyses only account for inputs such as class size, per pupil expenditure, or the fraction of teachers with an advanced degree. Measures of teacher development, data driven instruction, school culture, and student expectations have never been collected systematically, despite decades of qualitative research suggesting their importance (see reviews in Edmunds 1979, 1982).

In this paper, we provide new evidence on the determinants of school effectiveness by collecting unparalleled data on the inner-workings of 35 charter schools in New York City and correlating these data with credible estimates of each school's effectiveness. An enormous amount of information was collected from each school. A principal interview asked about teacher development, instructional time, data driven instruction, parent outreach, and school culture. Teacher interviews asked about professional development, school policies, school culture, and student assessment. Stu-

\footnotetext{
${ }^{1}$ Krueger (2003) argues that resources are systematically related to student achievement when the studies in Hanushek (1997) are given equal weight. It is only when each estimate is counted separately, as in Hanushek (1997), that the relationship between resources and achievement is not significant.
} 
dent interviews asked about school environment, school disciplinary policy, and future aspirations. Lesson plans were used to measure curricular rigor. Videotaped classroom observations were used to calculate the fraction of students on task throughout the school day.

Schools in our sample employ a wide variety of educational strategies and philosophies, providing dramatic variability in school inputs. For instance, the Bronx Charter School for the Arts believes that participation in the arts is a catalyst for academic and social success. The school integrates art into almost every aspect of the classroom, prompting students to use art as a language to express their thoughts and ideas. At the other end of the spectrum are a number of so-called "No Excuses" schools, such as KIPP Infinity, the HCZ Promise Academies, and the Democracy Prep Charter School. These "No Excuses" schools emphasize frequent testing, dramatically increased instructional time, parental pledges of involvement, aggressive human capital strategies, a "broken windows" theory of discipline, and a relentless focus on math and reading achievement (Carter 2000, Thernstrom and Thernstrom 2004, Whitman 2008). This variability, combined with rich measures of school inputs and credible estimates of each school's impact on student achievement, provides an ideal opportunity to understand which inputs best explain school effectiveness.

Our new data are interesting and informative. Input measures associated with a traditional resource-based model of education - class size, per pupil expenditure, the fraction of teachers with no teaching certification, and the fraction of teachers with an advanced degree - are not correlated with school effectiveness in our sample. Indeed, our data suggest that increasing resource-based inputs may actually lower school effectiveness. Schools with more certified teachers have annual math gains that are 0.043 (0.022) standard deviations lower than other schools. Schools with more teachers with a masters degree have annual ELA gains that are 0.034 (0.019) standard deviations lower. An index of class size, per pupil expenditure, the fraction of teachers with no teaching certification, and the fraction of teachers with an advanced degree, explains about 15 percent of the variance in charter school effectiveness, but in the unexpected direction.

In stark contrast, an index of five policies suggested by forty years of qualitative case-studies - frequent teacher feedback, data driven instruction, high-dosage tutoring, increased instructional time, and a relentless focus on academic achievement - explains roughly half of the variation in school effectiveness. A one standard deviation $(\sigma)$ increase in the index is associated with a $0.056 \sigma(0.011)$ increase in annual math gains and a $0.039 \sigma(0.010)$ increase in annual ELA gains. Moreover, four out of the five school policies in our index make a statistically significant contribution controlling for an index of the other four, suggesting that each policy conveys some relevant information. Controlling 
for the other four inputs, schools that give formal or informal feedback ten or more times per semester have annual math gains that are $0.038 \sigma(0.022)$ higher and annual ELA gains that are $0.028 \sigma(0.015)$ higher than other schools. Schools that tutor students at least four days a week in groups of six or less have annual math gains that are $0.044 \sigma(0.026)$ higher than other schools, and ELA gains that are $0.064 \sigma(0.021)$ higher. Schools that add 25 percent or more instructional time have annual gains that are $0.059 \sigma(0.015)$ higher in math.

We conclude our analysis by exploring the robustness of our results across three dimensions. First, we demonstrate that the main results are unchanged when accounting for three alternative theories of schooling: a model emphasizing the social and emotional needs of the "whole child" through wrap-around services and parental engagement, a model focused solely on the selection and retention of teacher talent, and the so-called "No Excuses" model of education. Second, we show that the results are unaffected if we control for an index of 37 other control variables collected for the purposes of this research. Third, we show that our main results are qualitatively similar in a larger sample of charter schools in NYC, using more coarse administrative data from site visits, state accountability reports, and school websites.

Our analysis has three important caveats. First, our estimates of the relationship between school inputs and school effectiveness are unlikely to be causal given the lack of experimental variation in school inputs. Unobserved factors such as principal skill, student selection into lotteries, or the endogeneity of school inputs could drive the correlations reported in the paper. Second, our estimates come from a subset of charter schools in New York City. Although participating schools are similar to other urban charter schools, they could differ in important ways that limit our ability to generalize our results. Moreover, there may be inputs common to almost all of the schools in our sample (e.g. a non-unionized staff) that have important interactions with other inputs. An important next step is to inject the strategies identified here into a set of traditional public schools (see Fryer 2011 for preliminary evidence from Houston). Third, while our data are remarkably rich, we cannot test every dimension of the alternative theories of education described above. For instance, advocates of the "whole child" approach will (correctly) argue that our data provide only a partial test of what is inevitably a rich, complex, and interlocking theoretical construct.

The paper is structured as follows. Section 2 provides a brief overview of the literature examining ways to increase school effectiveness. Section 3 describes the data collected for our analysis. Section 4 details our empirical strategy to estimate a school's effectiveness and reports treatment effects for our sample of charter schools. Section 5 provides a series of partial correlations of school inputs 
and school effectiveness. Section 6 concludes. There are three online appendices. Online Appendix A describes our sample and variable construction. Online Appendix B outlines our data collection process. Online Appendix C provides information on the lottery data from each charter school.

\section{A Brief Review of the Literature}

There is a large literature investigating ways to increase educational efficiency. We divide the literature into three parts: (1) evaluations of market based mechanisms such as school choice and school vouchers, (2) quantitative attempts to link school inputs to student performance, and (3) qualitative analyses of the strategies embedded in effective schools. We briefly describe each of these literatures in turn.

\section{A. Market Based Reforms}

Early research estimating the impact of school competition on school efficiency exploits variation in private school enrollment as a proxy for competitive pressure. Couch et al. (1993) finds a positive relationship between district-wide average test scores at public schools and the fraction of local students in private schools, which he interprets as evidence of a competition effect. Subsequent studies using the same approach on different data find smaller and generally insignificant effects (Newmark 1995, Sander 1999, Geller et al. 2006). Hoxby (1994) argues that private school enrollment endogenously responds to the quality of local public schools. Using the fraction of Catholics in a metropolitan area as an instrument for private enrollment, Hoxby (1994) reports that a ten percent increase in the fraction of a county enrolled in Catholic schools increases educational attainment by 0.33 years and wages by two percent. Conversely, Winters (forthcoming) finds that schools losing more students to charter schools are largely unaffected by the competitive pressures of the charter option.

A second and related group of studies examines the impact of Tiebout competition between public school districts. Borland and Howsen (1992) use the Herfindahl index of enrollment shares at different school districts as a measure of Tiebout competition, finding a slightly negative effect of competition on test scores. Arguing that district fragmentation is endogenous, Hoxby (2000) uses the number of rivers and streams in a metropolitan area as an instrument for the Herfindahl index. While Hoxby (2000) reports a positive impact of competition on student achievement, Rothstein (2006b) finds no effect of district fragmentation on the degree of sorting between school districts, suggesting that inter-district competition effects are small. 
A third strand of the literature examines the impact of private school vouchers on public school efficiency. Consistent with theoretical analyses by Epple and Romano (1998) and Nechyba (2000), Hsieh and Urquiola (2006) find that the expansion of private school vouchers in Chile led to increased stratification across schools, with few gains in student outcomes. Hoxby (2003), Carnoy et al. (2007), and Chakrabarti (2008) use the expansion of the Milwaukee Parental Choice Program to estimate the impact of school vouchers on school efficiency in non-voucher schools, finding evidence that student performance improved in the first few years of the expansion. However, Carnoy et al. (2007) find few gains at non-voucher schools after the initial voucher expansion. ${ }^{2}$

\section{B. SchOOL InPuts}

An immense literature relating school inputs to student achievement has developed in the wake of the Coleman Report (Coleman et al. 1966). In a meta-analysis of close to 400 studies, Hanushek (1997) finds that there is little evidence of a relationship between student performance and school resources after family background is taken into account. However, Krueger (2003) argues that resources are systematically related to student achievement when the studies in Hanushek (1997) are given equal weight. It is only when each estimate is counted separately, as in Hanushek (1997), that the relationship between resources and achievement is not significant.

Two recent papers attempt to link charter school characteristics and student achievement gains. Using data from 32 charter schools in NYC, Hoxby and Muraka (2009) find that an additional ten instructional days is associated with a $0.2 \sigma$ increase in annual achievement gains. Angrist, Pathak, and Walters (2011) use data from 30 charter schools in Massachusetts to show that urban charter schools are more effective at raising test scores than non-urban charter schools. Like many others, they argue that adherence to the so-called "No Excuses" paradigm can account for the nearly all of the urban advantage (Carter 2000, Thernstrom and Thernstrom 2004). Both Hoxby and Muraka (2009) and Angrist, Pathak, and Walters (2011) lack the kind of detailed within the school data used in this paper.

\section{Case-Studies of Effective Schools}

\footnotetext{
${ }^{2}$ An emerging literature uses randomized admission lotteries to estimate the impact of exercising the school choice option. Peterson et al. (1998) and Howell and Peterson (2002) find that attending a private school modestly increases student achievement for low-achieving African-American students in New York City, Dayton, and Washington, DC. A reanalysis of the New York City experiment by Krueger and Zhu (2004), however, suggests little impact of receiving a school voucher. Cullen et al. (2006), using randomized admission lotteries to magnet high schools in Chicago, find little impact of attending a better high school on academic achievement. Similarly, Hastings et al. (2006) find little impact of attending a "first-choice" school in Charlotte-Mecklenburg on achievement, though Deming (forthcoming) and Deming et al. (2011) find a positive impact on crime and college attendance.
} 
Qualitative researchers have amassed a large literature exploring the attributes of effective schools. In 1974, New York's Office of Education Performance Review analyzed two NYC public schools serving disadvantaged students, one highly effective, one not. The study concluded that differences in academic achievement were driven by differences in principal skill, expectations for students, and classroom instruction. Madden, Lawson and Sweet (1976) examined 21 pairs of California elementary schools matched on pupil characteristics, but differing in student achievement. The more effective schools were more likely to provide teacher feedback, tutor their students, monitor student performance, and have classroom cultures more conducive to learning. Brookover and Lezotte (1977) found similar results for a set of schools in Michigan. Summarizing the literature, Edmonds (1979) argued that effective schools tend to have a strong administrative leadership, high expectations for all children regardless of background, an atmosphere conducive to learning, a focus on academic achievement, and frequent monitoring of student progress.

A more recent branch of this literature focuses on the characteristics of so-called "No Excuses" schools, loosely defined as schools that emphasize strict discipline, extended time in school, and an intensive focus on building basic reading and math skills. Using observations from 21 high poverty high performing schools, Carter (2000) argues that "No Excuses" schools succeed due to empowered principals, the use of interim assessments to measure student progress, frequent and effective professional development, aggressive parent outreach, and a relentless focus on achievement for all students regardless of background. Thernstrom and Thernstrom (2004) similarly argue that "No Excuses" schools are more effective due to more instructional time, a zero tolerance disciplinary code, high academic expectations for all students, and an emphasis on teaching basic math and reading skills (see Whitman 2008 for similar arguments).

\section{Constructing a Database on the Inner-Workings of Schools}

The main data for this paper are gathered from two sources: (1) school specific data collected from principal, teacher, and student surveys, lesson plans, and videotaped observations of classroom lessons, and (2) administrative data on student demographics and outcomes from the New York City Department of Education (NYCDOE). Below, we describe each data source. 


\subsection{School Characteristics Data}

In the spring of 2010, we attempted to collect survey, lottery, and video data for all charter schools in New York City with students in grades 3 - 8. Eligible schools were invited to participate via email and phone. We also hosted an informational event at the New York Charter Center to explain the project to interested schools. Schools were offered a $\$ 5000$ stipend to be received conditional on providing all of the appropriate materials. Of the 48 eligible charter elementary schools (entry grades $\mathrm{K}-4$ ) and 37 eligible charter middle schools (entry grades 5 - 8), 22 elementary schools and 13 middle schools chose to participate in the study. Within the set of participating schools, 13 elementary schools and 9 middle schools also provided admissions lottery data. The other 13 schools were either under-subscribed or did not keep usable lottery records. Table 1 summarizes the selection process. Appendix Table 1 lists each participating school, along with the data that is available for each school.

An enormous amount of information was collected from participating schools. A principal interview asked about teacher and staff development, instructional time, data driven instruction, parent outreach, and school culture. An hour long follow up phone interview with each school leader provided additional details on each domain. Information on curricular rigor was coded from lesson plans collected for each testable grade level in both math and ELA. Finally, information on school culture and practices was gathered during full day visits to each school. These visits included videotaped classroom observations of at least one math and reading class and interviews with randomly chosen teachers and students. Below we describe the variables we code from this data. Additional details on the data are available in Online Appendix A. Full survey and interview scripts are available in Online Appendix B.

\section{A. Human Capital}

A school's human capital policies are captured through the number of times a teacher receives formal or informal feedback from classroom visits, how many hours teachers spend on instructional and non-instructional activities during a normal week, the highest teacher salary at the school, the fraction of teachers who leave involuntarily each year, and the number of non-negotiables a school has when hiring a new teacher. See Online Appendix B for further details.

Summary statistics for our human capital data are displayed in Table 2. We split our sample into more and less effective schools based on estimates described in Section 4. Specifically, we separate the sample at the median using the average of each school's estimated impact on math 
and ELA scores. Consistent with Edmonds (1979, 1982), high achieving schools have more intensive human capital policies than other schools. The typical teacher at a high achieving elementary school receives feedback 16.41 times per semester, compared to 11.31 times at other charter schools. The typical teacher at a high achieving middle school receives feedback 13.42 times per semester, 6.35 more instances of feedback than teachers at other charter schools. Teachers at high achieving schools also work longer hours than teachers at other charter schools; an additional 7.75 hours per week at the elementary level and 10.29 hours per week at the middle school level. Despite this higher workload, the maximum salary of teachers at high achieving schools is the same or somewhat lower than other charter schools.

\section{B. The Use of Data in Instructional Practice}

We attempt to understand how schools use data through the frequency of interim assessments, whether teachers meet with a school leader to discuss student data, how often teachers receive reports on student results, and how often data from interim assessments are used to adjust tutoring groups, assign remediation, modify instruction, or create individualized student goals.

Summary statistics for our data driven instruction variables are displayed in Table 2. High achieving schools use data more intensely than other charter schools in our sample. High achieving elementary schools test students 3.92 times per semester, compared to 2.42 times at other charter schools. Higher achieving middle schools test students 4.00 times, compared to 2.04 times at other charter middle schools in our sample. Higher achieving schools are also more likely to track students using data and utilize more differentiation strategies compared to low achieving schools.

\section{Parental Engagement}

Parent outreach variables capture how often schools communicate with parents due to academic performance, due to behavioral issues, or to simply provide feedback.

Summary statistics in Table 2 suggest that high achieving elementary and middle schools provide more feedback of all types to parents. Higher achieving schools provide academic feedback 3.00 more times per semester than other schools, behavioral feedback 9.20 more times per semester, and general feedback to parents 7.27 more times per semester.

\section{High-Dosage Tutoring}

Tutoring variables measure how often students are tutored and how large the groups are. We code a school as offering small group tutoring if the typical group is six or fewer students. Schools 
are coded as offering frequent tutoring if groups typically meet four or more times per week. Finally, schools are coded as having high-dosage tutoring if the typical group is six or fewer students and those groups meet four or more times per week.

While almost all charter schools in our sample offer some sort of tutoring, high achieving charter schools in our sample are far more likely to offer high-dosage tutoring. Thirty-three percent of high achieving elementary schools offer high-dosage tutoring compared to ten percent of low achieving schools. Seventeen percent of high achieving middle schools offer high-dosage tutoring, while none of the low achieving schools do.

\section{E. Instructional Time}

Instructional time is measured through the length and number of instructional days and the number of minutes spent on math and ELA in each school.

High achieving charter schools in our sample have a longer instructional year and day than other charter schools. The typical high achieving elementary school has 190.67 instructional days and an instructional day of 8.07 hours, compared to 183.80 instructional days and 7.36 instructional hours at other charter schools. The typical high achieving middle school meets for 191.00 instructional days, with a typical instructional day lasting 8.17 hours. Other charter middle schools in our sample meet for only 187.14 instructional days with an average day of 7.87 hours. In other words, high achieving elementary schools provide about 26.68 percent more instructional hours per year than a typical NYC schools, while high achieving middle schools provide about 28.07 percent more. Other charter schools, on the other hand, provide just 11.39 and 21.38 percent more instructional time at the elementary and middle school levels respectively. ${ }^{3}$

\section{F. Culture and Expectations}

School culture is measured through two sets of questions. The first set of questions asks leaders to rank ten school priorities. We code a school as having high academic and behavioral expectations if an administrator ranks "a relentless focus on academic goals and having students meet them" and "very high expectations for student behavior and discipline" as her top two priorities (in either order). Other potential priorities include "a comprehensive approach to the social and emotional needs of the whole child," "building a student's self-esteem through positive reinforcement," and "prioritizing each child's interests and passions in designing a project-based unit."

\footnotetext{
${ }^{3}$ Traditional public schools in NYC meet for 180 instructional days and 6.0 to 7.5 instructional hours each day. We assume a 6.75 hour instructional day when calculating changes in instructional time.
} 
The second set of culture questions consists of ten multiple choice questions written for the purposes of this study by the founder of the MATCH charter high school in Boston, a prominent "No Excuses" adherent. The questions ask about whether rules are school-wide or classroom specific, how students learn school culture, whether students wait for the teacher to dismiss the class, desk and backpack rules, hallway order, classroom activities, and whether students track teachers with their eyes. We create a dichotomous variable for each question equal to one if a school leader indicates a "No Excuses," or more strict, disciplinary policy. Our measure of a school's disciplinary policy is the standardized sum of the ten dichotomous variables.

Consistent with past research (e.g. Edmunds 1979, 1982, Carter 2000, Thernstrom and Thernstrom 2004), high achieving charter schools are more likely to have higher academic and behavioral expectations compared to other charter schools and are more likely to have school-wide disciplinary policies.

\section{G. Lesson Plans}

The rigor of a school's curriculum is coded from lesson plans collected from each testable grade level and subject area in a school. We code whether the most advanced objective for each lesson is at or above grade level using New York State standards for the associated subject and grade. Lesson plan complexity is coded using the cognitive domain of Bloom's taxonomy which indicates the level of higher-order thinking required to complete the objective. In the case where a lesson has more than one objective, the most complex objective was chosen. We also code the number of differentiation strategies present in each lesson plan and the number of checks for understanding. Finally, we create an aggregate thoroughness measure that captures whether a lesson plan includes an objective, an essential question, a do-now, key words section, materials section, introduction section, main learning activity, a check for understanding, an assessment, a closing activity, time needed for each section, homework section, teacher reflection section, and if the lesson plan follows a standardized format. The inclusion of each element increases the thoroughness measure by one, which is then standardized to have a mean of zero and a standard deviation of one.

Surprisingly, lesson plans at high achieving charter schools are not more likely to be at or above grade level and do not have higher Bloom's Taxonomy Scores. Higher achieving charter schools also

appear no more likely to have more differentiated lesson plans and appear to have less thorough lesson plans than lower achieving charter schools. Above median elementary schools have an average of 4.67 items on our lesson plan thoroughness measure, while lower achieving scores have 5.12. The 
gap between above and below median middle schools is even larger, with above median schools having 5.50 items and below median schools averaging 6.83 items.

\subsection{Administrative Data}

Our second data source consists of administrative data on student demographics and outcomes from the New York City Department of Education (NYCDOE). The data include information on student race, gender, free and reduced-price lunch eligibility, behavior, attendance, and state math and ELA test scores for students in grades three through eight. The NYCDOE data span the 2003 - 2004 to 2009 - 2010 school years.

The state math and ELA tests, developed by McGraw-Hill, are high-stakes exams conducted in the spring semester of third through eighth grade. The math test includes questions on number sense and operations, algebra, geometry, measurement, and statistics. Tests in the earlier grades emphasize more basic content such as number sense and operations, while later tests focus on advanced topics such as algebra and geometry. The ELA test is designed to assess students on their information and understanding, literary response and expression, and critical analysis and evaluation. The ELA test includes multiple-choice and short-response sections based on a reading and listening section, as well as a brief editing task.

All public-school students, including those attending charters, are required to take the math and ELA tests unless they are medically excused or have a severe disability. Students with moderate disabilities or who are English Language Learners must take both tests, but may be granted special accommodations (additional time, translation services, and so on) at the discretion of school or state administrators. In our analysis the test scores are normalized to have a mean of zero and a standard deviation of one for each grade and year across the entire New York City sample.

Student level summary statistics for the variables that we use in our core specifications are displayed in Table 3. Charter students are more likely to be black and less likely to be English language learners or participate in special education compared to the typical NYC student. Charter students receive free or reduced price lunch at similar rates as other NYC students. Charter middle school students score $0.08 \sigma$ lower in fifth grade math and $0.06 \sigma$ lower in fifth grade ELA compared to the typical NYC student. Students in our sample of charter schools score $0.12 \sigma$ lower in math and $0.08 \sigma$ lower in ELA compared to the typical charter student in NYC, suggesting that schools in our sample are negatively selected (on test score levels) from the NYC charter school population as a whole. 


\section{The Impact of Attending a NYC Charter School}

To estimate the causal impact of each school in our sample, we use two empirical models. The first exploits the fact that oversubscribed charter schools in NYC are required to admit students via random lottery. The second statistical model uses a combination of matching and regression analysis to partially control for selection into charter schools.

Following Hoxby and Muraka (2009), Abdulkadiroglu et al. (2011), and Dobbie and Fryer (2011), we model the effect of a charter school on student achievement as a linear function of the number of years spent at the school:

$$
\text { achievement }_{i g t}=\alpha_{t}+\lambda_{g}+\beta X_{i}+\rho \text { Charter }_{i g t}+\varepsilon_{i g t}
$$

where $\alpha_{t}$ and $\lambda_{g}$ and year and grade of test effects respectively, $X_{i}$ is a vector of demographic controls including gender, race, free lunch status, and baseline test scores. $\varepsilon_{i g t}$ is an error term that captures random variation in test scores.

The causal effect of attending a charter school is $\rho$. If the number of years a student spends at a charter was randomly assigned, ordinary least squares (OLS) estimates of equation (1) would capture the average causal effect of years spent at the school. Because students and parents selectively choose whether to enroll at a charter school, however, OLS estimates are likely to be biased by correlation between school choice and unobserved characteristics related to student ability, motivation, or background.

To identify $\rho$ we use an instrumental variables (IV) strategy that exploits the fact that New York law dictates that over-subscribed charter schools allocate enrollment offers via a random lottery.

The first stage equations for IV estimation take the form:

$$
\text { Charter }_{i g t}=\mu_{t}+\kappa_{g}+\gamma X_{i}+\pi Z_{i}+\sum_{j} \nu_{j} \text { Lotter }_{i j}+\eta_{i g t}
$$

where $\pi$ captures the effect of the lottery offer $Z_{i}$ on the number of years a student spends at a charter school. The lottery indicators Lottery L $_{i j}$ are lottery fixed effects for each of the school's $j$ lotteries. We also control for whether the student had a sibling in a lottery that year. We estimate the impact of each school separately within the pool of lottery applicants. We stack test scores and cluster standard errors at the student level.

Our lottery sample is drawn from each lottery that took place between 2003 and 2009 at our 
sample schools. We make three sample restrictions. First, applicants with a sibling already at a school are excluded, as they are automatically admitted. Second, applicants are dropped who, because of within-district preference introduced in 2008, had either no chance of winning the lottery or were automatically granted admission. Finally, we include only the first application of students who apply to a school more than once. These restrictions leave us with a sample of 9,850 lottery students in 58 lotteries at 22 schools. Appendix C describes the lottery data from each school in more detail.

Columns 5 and 6 of Table 3 present summary statistics for lottery applicants in our lottery sample. As a measure of lottery quality, Table 3 also tests for balance on baseline characteristics. Specifically, we regress an indicator for winning the lottery on pretreatment characteristics and lottery fixed effects. Elementary lottery winners are 0.03 percentage points less likely to be eligible for free and reduced price lunch compared to Elementary lottery losers. Middle school lottery winners are 0.01 percentage points less likely to be English language learners. There are no other significant differences between lottery winners and lottery losers. This suggests that the lottery is balanced and that selection bias should not unduly affect our lottery estimates.

An important caveat to our lottery analysis is that lottery admissions records are only available for 22 of our 35 schools. To get an estimate of school effectiveness for schools in our sample that do not have valid lottery data or are not oversubscribed, our second empirical strategy computes observational estimates. Following Angrist et. al (2011), we use a combination of matching and regression estimators to control for observed differences between students attending different types of schools. First, we match students attending sample charters to a control sample of traditional public school students using the school a student is originally zoned to, cohort, sex, race, limited English proficiency status, and free and reduced price lunch eligibility. Charter students are included in the observational estimates if they are matched to at least one regular public school student. Traditional school students are included if they are matched to at least one charter student. This procedure yields matches for 94.3 percent of students in charter schools in our sample.

Within the group of matched charter and traditional public school students, we estimate equation (1) controlling for baseline test scores and fixed effects for the cells constructed in the matching procedure. Specifically, the observational estimates were constructed by fitting:

$$
\text { achievement }_{\text {igtc }}=\sigma_{t}+\tau_{g}+\iota_{c}+\varphi X_{i}+\theta_{s} \text { Charter }_{\text {igts }}+\zeta_{\text {igts }}
$$


where $\sigma_{t}$ and $\tau_{g}$ and year and grade of test effects respectively, $X_{i}$ is a vector of demographic controls including baseline test scores and years enrolled in charters not in our sample, $\iota_{c}$ are match cell fixed effects, and Charterigts is a vector of the number of years spent in each charter in our sample. The observational estimates therefore compare demographically similar students zoned to the same school and in the same age cohort, who spend different amounts of time in charter schools. We stack student observations for all schools in our sample, and cluster standard errors at the student level.

Table 4 reports a series of results on the impact of attending charter schools on student achievement in our sample. We report reduced-form (column 1), first stage (column 2), and instrumental variable estimates from our lottery sample (column 3), a non-experimental estimate of our lottery sample (column 4), and a non-experimental estimate that includes schools without oversubscribed lotteries (column 5). We estimate effects for elementary and middle schools separately. All regressions control for grade and year effects, gender, race, free lunch status, lottery cohort, and previous test scores in the same subject.

Elementary school lottery winners outscore lottery losers by $0.119 \sigma(0.029)$ in math and $0.056 \sigma$ (0.027) in ELA. Middle school lottery winners outscore lottery losers by $0.064 \sigma(0.015)$ in math and $0.023 \sigma(0.014)$ in ELA. The lottery first stage coefficient is 0.755 (0.054) for elementary school, and 0.403 (0.024) for middle school. In other words, by the time they were tested, elementary school lottery winners had spent an average of 0.755 more years at a charter school than lottery losers. This first stage is similar to lottery winners at other urban charter schools (Abdulkadiroglu et al. 2011, Angrist et al. 2010). The two-stage least squares (2SLS) estimate, which captures the causal effect of attending a charter school for one year, is $0.158 \sigma(0.038)$ in math and $0.074 \sigma(0.036)$ in ELA for elementary schools, and $0.159 \sigma(0.037)$ in math and $0.057 \sigma(0.034)$ in ELA for middle schools. The magnitude of these results is consistent with other work on "No Excuses" charter schools (Abdulkadiroglu et al. 2011, Angrist et al. 2010, Dobbie and Fryer 2011), but larger than the average charter in New York (Hoxby and Muraka 2009). The larger estimates could be due to an increase in school effectiveness since the Hoxby and Muraka study, or positive selection into our sample.

Column 4 of Table 4 presents observational results for our lottery charter schools. Our observational estimates imply that elementary charter students score $0.054 \sigma(0.004)$ higher in math for each year they attend a charter school, and $0.050 \sigma$ (0.003) in ELA. Middle school charter students gain $0.051 \sigma(0.004)$ in math and $0.013 \sigma(0.004)$ in ELA for each year they attend a charter. The 
observational are qualitatively similar to the lottery estimates, though smaller in magnitude. This suggests that while matching and regression control for some of the selection into charter schools, observational estimates are still downwards biased relative to the true impact of charter schools. Observational estimates for the full sample of charters are somewhat lower compared to the lottery sample.

Figure 1 plots lottery and observational estimates for the 22 schools in our lottery sample. Regressing each school's lottery estimate on that school's observational estimate results in a coefficient of 0.768 (0.428) for math and 0.526 (0.597) for ELA, suggesting that our observational estimates at least partially control for selection bias. With that said, Figure 1 also suggests that our observational estimates are biased downwards and have less variance than the corresponding lottery estimates. For instance, the lottery estimates for math have a standard deviation of 0.251 , while the observational estimates have a standard deviation of 0.142 . Estimates for ELA reveal a similar pattern.

\section{Getting Beneath the Veil of Effective Schools}

\subsection{Main Results}

In this section, we present a series of partial correlations between strategies and policies that describe the inner workings of schools and each school's effectiveness at increasing student test scores. The specifications estimated are of the form:

$$
\theta_{s}=\text { constant }+\varphi M S_{s}+\vartheta P_{s}+\xi_{s}
$$

where $\theta_{s}$ is an estimate of the effect of charter school $s, M S_{s}$ is an indicator for being a middle school, and $P_{s}$ is a vector of school policies and school characteristics measured in our survey and video observations. The estimates of equation (4) are weighted by the inverse of the standard error of the estimate treatment effect $\theta_{s}$. Standard errors are clustered at the school level to account for correlation between elementary and middle school campuses. Unless otherwise noted, we use observational estimates of $\theta_{s}$, which increases our sample size from 22 to 35 . Our main results are qualitatively unchanged using lottery estimates, though the estimates are less precise (see Appendix Tables 2 through 5).

The parameter of interest is $\vartheta$, which measures the partial correlation of a given school char- 
acteristic on effectiveness. Recall, our estimates are not likely to be causal in nature. Unobserved factors such as principal ability or parental involvement could drive the correlation between our measures and school effectiveness.

As mentioned in Section 2, there is a voluminous literature relating school inputs to average test scores. The typical dataset includes variables such as class size, per pupil expenditure, and teacher credentials. With the notable exception of a number of quasi-experimental studies finding a positive impact of class size on test scores, previous research has found little evidence linking these inputs to achievement (see reviews in Hanushek 1997 and Krueger 2003).

Table 5 presents results using several of the traditionally collected school inputs - class size, per pupil expenditure, the fraction of teachers with no certification, and the fraction of teachers with a masters degree - as explanatory variables for school effectiveness. For each measure we create an indicator variable equal to one if a school is above the median in that measure. Consistent with Hanushek (1997), we find that these measures are either statistically unrelated to school effectiveness or are significant in an unexpected direction. For instance, schools where at least 89 percent of teachers are certified have annual math gains that are $0.043 \sigma(0.022)$ lower. Schools where at least eleven percent of teachers have a masters degree have annual ELA gains that are $0.034 \sigma(0.019)$ lower. An index of the four dichotomous measures explains 13.6 to 20.4 percent of the variance in charter school effectiveness but in the unexpected direction. ${ }^{4}$

In stark contrast, Table 6 demonstrates that the five policies suggested most often by the qualitative literature on successful schools (Edmunds 1979, 1982) - teacher feedback, the use of data to guide instruction, tutoring, instructional time, and a culture of high expectations - explain around 50 percent of the variance in charter school outcomes. Schools that give formal or informal feedback ten or more times per semester have annual math gains that are $0.075 \sigma(0.021)$ higher and annual ELA gains that are $0.054 \sigma(0.017)$ higher than other schools. Schools that give five or more interim assessments during the school year and that have four or more differentiation strategies have annual math and ELA gains that are $0.078 \sigma(0.036)$ and $0.045 \sigma(0.029)$ higher, respectively. Schools that tutor students at least four days a week in groups of six or fewer have $0.069 \sigma(0.033)$ higher math scores and $0.078 \sigma(0.025)$ higher ELA scores. Schools that add 25 percent or more instructional time

\footnotetext{
${ }^{4}$ One concern is that charter schools do not use resource-based inputs at the same rate as traditional public schools. This does not appear to be the case, though its possible. According to the NYCDOE, for example, charter elementary schools have class sizes that range from 18 to 26 students per class and charter middle schools have class sizes ranging from 22 to 29 students. In 2010 - 2011, the average class size in a traditional elementary school in NYC was 23.7 students and the average class size in a traditional middle school was 26.6 to 27.1 students, depending on the subject.
} 
compared to traditional public schools have annual gains that are $0.084 \sigma(0.022)$ higher in math and $0.043 \sigma(0.024)$ higher in ELA. Whether or not a school prioritizes high academic and behavioral expectations for all students is associated with math gains that are $0.066 \sigma(0.028)$ higher than other schools and ELA gains that are $0.049 \sigma(0.019)$ higher per year. A one standard deviation increase in an index of all five dichotomous variables is associated with a $0.056 \sigma(0.011)$ increase in annual math gains and a $0.039 \sigma(0.010)$ increase in annual ELA gains. ${ }^{5}$

Table 7 estimates the partial correlation of each of the five policies on school effectiveness, controlling for the other four. Surprisingly, four out of the five policy measures used in our index continue to be statistically significant, suggesting that each policy conveys some relevant information. Controlling for other school policies, schools that give formal or informal feedback ten or more times per semester have annual math gains that are $0.038 \sigma(0.022)$ higher and annual ELA gains that are $0.028 \sigma(0.015)$ higher than other schools. Schools that give five or more interim assessments during the school year and that have four or more differentiation strategies have annual math and ELA gains that are $0.051 \sigma(0.022)$ higher. The lack of significance in ELA is intuitive, as it is less clear how to use data to inform reading instruction relative to math. Schools that add 25 percent or more instructional time compared to traditional public schools have annual gains that are $0.059 \sigma$ (0.015) higher in math, though not in ELA. Controlling for other policies, schools that prioritize high-dosage tutoring have annual math gains that are $0.044 \sigma(0.026)$ higher than other schools and ELA gains that are $0.064 \sigma(0.021)$ higher.

\subsection{Robustness Checks}

In this subsection, we explore the robustness of our results by accounting for a more diverse set of controls and performing an out of sample test of our main index.

\section{A. Three Alternative Models of School Effectiveness}

Our first robustness test attempts to account for three alternative models of effective schooling put forth in the literature. The first model we test emphasizes the importance of taking into account the social and emotional needs of the "whole child" through wrap-around services. Advocates of

\footnotetext{
${ }^{5}$ While the index variable is associated with large and statistically significant gains in the lottery sample, the measure only explains 18.4 percent of the variance in math effectiveness and 8.8 percent of the variation in ELA effectiveness in the lottery sample. The relatively low $R^{2}$ is most likely due to the imprecision of the lottery estimates of school effectiveness; only 7 of the 22 schools have statistically significant results in either subject when using our lottery estimation strategy. The reduction in sample size from 35 to 22 schools itself does not appear important, however. The index measure explains over 50 percent of the variation in both math and ELA effectiveness among the 22 lottery schools when using observational measures of effectiveness.
} 
this approach argue that teachers and school administrators are dealing with issues that originate outside the classroom, citing research that shows racial and socioeconomic achievement gaps are formed before children ever enter school (Fryer and Levitt 2004, 2006) and that one-third to one-half of the gap can be explained by family-environment indicators (Phillips et al. 1998, Fryer and Levitt 2004). In this scenario, combating poverty and having wrap-around services that address some of the social and emotional needs of students may lead to more focused instruction in school. In a meta-analysis, Payton et al. (2008) estimate that school-wide social-emotional learning programs increase achievement by $0.28 \sigma$, that programs that target at-risk individuals increase achievement by $0.43 \sigma$, and that after school programs raise achievement by $0.08 \sigma$.

To partially test this theory, we create a set of indicator variables equal to one if a school has a school social worker, provides health services, provides any wrap-around services, and if they rank "a comprehensive approach to the social and emotional needs of the whole child," as one of their top two school priorities. Our index of wrap-around services is the standardized sum of these four dichotomous variables. The first two columns in panels A and B of Table 8 present the correlation between wrap-around services and school effectiveness with and without controlling for our main index.

A one standard deviation increase in wrap-around services is associated with a $0.025 \sigma(0.014)$ decrease in annual math gains and a statistically insignificant $0.018 \sigma(0.012)$ decrease in annual ELA gains. Consistent with the findings in Dobbie and Fryer (2011), there is not a statistically significant relationship between providing a comprehensive approach to the "whole child" through wrap-around services that we are able to measure and school effectiveness after controlling for our main index. Perhaps more importantly, the coefficient on our main index after controlling for wrap-around service provision is statistically indistinguishable from the specification without these controls. As discussed in the Introduction, however, our data provide only a partial test of the "whole child" model of schooling.

The second model we account for emphasizes the selection and retention of talented teachers. Teacher quality is believed to be one of the most important inputs into the educational production function. A one standard deviation increase in teacher quality raises math achievement by $0.15 \sigma$ to $0.24 \sigma$ per year and reading achievement by $0.15 \sigma$ to $0.20 \sigma$ per year (Rockoff 2004, Rivkin, Kain, and Hanushek 2005, Aaronson et al. 2007, Kane and Staiger 2008). The difficulty, however, is extremely difficult to identify ex ante the most productive teachers (see reviews in Hanushek 1986, 1997). As a result, many have argued that in addition to selecting better teachers, schools must 
remove ineffective teachers, and introduce pay-for-performance schemes in order to retain more effective teachers. For example, Hanushek (2009) argues that eliminating the worst six to ten percent of teachers would increase student achievement by about $0.5 \sigma$.

To test this hypothesis, we create a set of indicator variables equal to one if a school has an above median number of requirements when hiring a new teacher, if the school has above median involuntary turnover, if the school has an above median maximum salary, and if the school offers performance pay to teachers. Our index of teacher selection, retention, and pay, is the standardized sum of these four dichotomous variables.

The second two columns in panels A and B of Table 8 present results for these teacher selection strategies. Interestingly, higher values of our teacher index are associated with school effectiveness in math, but not ELA. ${ }^{6}$ The policy index suggested by the qualitative case-study literature is statistically identical whether or not we control for the index of teacher selection, retention, and pay.

The third model we test is whether the adherence to a "No Excuses" philosophy drives school success. As discussed by Carter (2000), Thernstrom and Thernstrom (2004), Whitman (2008), and others, "No Excuses" schools emphasize strict discipline, extended time in school, and an intensive focus on basic reading and math skills. Angrist et. al (2011) argue that adherence to the "No Excuses" philosophy explains the difference between the effectiveness of urban and non-urban charter schools in Massachusetts.

Similar to Angrist et al (2011), we create an indicator variable for whether a school is considered a follower of the "No Excuses" model of schooling. Consistent with previous research, Columns 5 and 13 of Table 8 demonstrate a strong correlation between being identified as a "No Excuses" school and school effectiveness (Monroe 1999, Carter 2000, Thernstrom and Thernstrom 2004, Angrist et al. 2011). Students at "No Excuses" schools gain $0.065 \sigma(0.029)$ more in math than students at other charter schools and a statistically insignificant $0.034 \sigma(0.020)$ more in ELA. Interestingly, however, after controlling for the the five factors in our main index, "No Excuses" schools do no better or worse than other charter schools.

The fact that the "No Excuses" designation becomes statistically insignificant when one accounts for five policies is striking and highly suggestive that their is nothing mystical about "No Excuses" schools. More time, more effective teachers, the use of data and high-dosage tutoring, and high

\footnotetext{
${ }^{6}$ Appendix Table 4 demonstrates some fragility in these results. The index of teacher selection, retention, and pay has the opposite sign and is marginally significant in our lottery sample.
} 
expectations seem to be more important predictors of school effectiveness, regardless of a school's overarching philosophy (e.g. "No Excuses," Montessori, or arts infused).

\section{B. Accounting for More Controls}

Our second robustness check simply accounts for every other measure of school inputs collected during the study that does not enter the main index. This control index is created by standardizing the sum of six indexes - human capital policies, data policies, parent engagement strategies, instructional time differences, culture and expectations, and curricular rigor - to have a mean of zero and a standard deviation of one. In total, the index captures variation in 37 measures, virtually all of the data we collected in the principal survey.

The final two columns of Table 8 present results controlling for the aggregate index of 37 variables. A one standard deviation increase in this aggregate index is associated with a $0.024 \sigma(0.014)$ increase in annual math gains, and a statistically insignificant $0.011 \sigma(0.007)$ increase in annual ELA gains. However, the control index is statistically indistinguishable from zero after controlling our main index. The coefficient on the main index is again statistically indistinguishable from the specification with no controls, which suggests the other variables collected do not convey any more statistically relevant information in explaining charter school success.

\section{An Out of Sample Test}

Our final robustness check explores the association between the school inputs in our main index and school effectiveness in a set of schools that did not participate in our survey. To do this, we collected similar (though more coarse) administrative data on human capital, data driven instruction, instructional time, and culture for every possible charter school in New York City. Despite an exhaustive search, we could not find any administrative data on whether or how these schools tutored students. Thus, our index for this out of sample test will contain four out of the five variables.

Our data is drawn primarily from annual site visit reports provided by each school's chartering organization. New York City charter schools are either authorized by the New York City Department of Education (NYCDOE), the State University of New York (SUNY), or the New York State Department of Education (NYSDOE). The site visits are meant to "describe what the reviewers saw at the school - what life is like there" (NYCDOE 2011). The report identifies some of the strengths in a school, as well as areas where improvement is needed. ${ }^{7}$ Thirty-one NYCDOE and

\footnotetext{
${ }^{7}$ Site visit reports chartered by the NYCDOE include quantitative rankings, from which we draw our measures. SUNY site visit reports are qualitative in nature. In the latter case, we code each variable directly from the text of the site visit report.
} 
twenty-five SUNY schools have both site visit reports and students in grades 3 - 8 . For this set of schools, we complement the site visit data with data from New York State Accountability and Overview Reports, the Charter School Center, and each school's website. More information on each data source and how we construct our variables to most closely match the variables collected in our survey is available in Online Appendix A.

Table 9 presents results using all eligible charter schools chartered with site visit data. The results of our out of sample test are similar to, though less precise than, the survey results. A one standard deviation increase in the case-study index is associated with a $0.025 \sigma(0.010)$ increase in math scores and a $0.011 \sigma(0.006)$ increase in ELA scores. However, the index explains less than seven percent of the variation in math and ELA, likely reflecting measurement error in the data. Instructional time and high academic and behavioral expectations are significantly related to achievement. The point estimates on teacher observations and data driven instruction are positive but not statistically significant.

\section{Conclusion}

Charter schools were created to (1) serve as an escape hatch for students in failing schools and (2) use their relative freedom to incubate best practices to be infused into traditional public schools. Consistent with the second mission, charter schools employ a wide variety of educational strategies and operations, providing dramatic variability in school inputs. Taking advantage of this fact, we collect unparalleled data on the inner-workings of 35 charter schools in New York City to understand what inputs are most correlated with school effectiveness. Our data include a wealth of information collected from each school through principal, teacher, and student surveys, sample teacher evaluation forms, lesson plans, homework, and video observations.

We show that input measures associated with a traditional resource-based model of education - class size, per pupil expenditure, the fraction of teachers with no teaching certification, and the fraction of teachers with an advanced degree - are not positively correlated with school effectiveness. In stark contrast, an index of five policies suggested by forty years of qualitative research - frequent teacher feedback, data driven instruction, high-dosage tutoring, increased instructional time, and a relentless focus on academic achievement - explains almost half of the variation in school effectiveness. Moreover, we show that these variables continue to be statistically important after accounting for alternative models of schooling, and a host of other explanatory variables, and are predictive in 
a different sample of schools.

While there are important caveats to the conclusion that these five policies can explain significant variation in school effectiveness, our results suggest a model of schooling that may have general application. The key next step is to inject these strategies into traditional public schools and assess whether they have a causal effect on student achievement. 


\section{References}

[1] Aaronson, Daniel, Lisa Barrow, and William Sander. 2007. "Teachers and Student Achievement in the Chicago Public High Schools," Journal of Labor Economics, 25: 95-135.

[2] Abdulkadiroglu, Atila, Joshua Angrist, Susan Dynarski, Thomas Kane, and Parag Pathak. 2011. "Accountability and Flexibility in Public Schools: Evidence from Boston's Charters and Pilots." Quarterly Journal of Economics, 126(2): 699-748.

[3] Altonji, Joseph G. and Thomas A. Dunn. 1995. "The Effects of School and Family Characteristics on the Return to Education." NBER Working Paper No. 5072.

[4] Altonji, Joseph G. and Thomas A. Dunn. 1996a. "Using Siblings to Estimate the Effect of School Quality on Wages." Review of Economics and Statistics, 78(4): 665-671.

[5] Altonji, Joseph G. and Thomas A. Dunn. 1996b. "The Effects of Family Characteristics on the Return to Schooling." Review of Economics and Statistics, 78(4): 692-704.

[6] Angrist, Joshua, Susan Dynarski, Thomas Kane, Parag Pathak, and Christopher Walters. 2010. "Who Benefits from KIPP?" NBER Working Paper No. 15740.

[7] Angrist, Joshua, Parag Pathak, and Christopher Walters. 2011. "Explaining Charter School Effectiveness." NBER Working Paper No. 17332.

[8] Arum, Richard. 1996. "Do Private Schools Forces Public Schools to Compete?" American Sociological Review, 61(1): 29-46.

[9] Aud, S., Hussar, W., Kena, G., Bianco, K., Frohlich, L., Kemp, J., Tahan, K. 2011. The Condition of Education 2011 (NCES 2011-033). U.S. Department of Education, National Center for Education Statistics. Washington, DC: U.S. Government Printing Office.

[10] Belfield, Clive R., and Henry M. Levin. 2002. "The Effects of Competition between Schools on Educational Outcomes: A Review for the United States Review of Educational Research." Review of Educational Research, 72(2): 279-341.

[11] Borland, Melvin V., and Roy M. Howsen. 1992. "Student Academic Achievement and the Degree of Market Concentration in Education." Economics of Education Review, 11(1): 31-39.

[12] Brookover, Wilbur, and Lawrence Lezotte. 1977. "Changes in School Characteristics Coincident with Changes in Student Achievement." Michigan State University, College of Urban Development. 
[13] Budde, Ray. 1988. "Education by Charter: Restructuring School Districts. Key to Long-Term Continuing Improvement in American Education," Regional Laboratory for Educational Improvement of the Northeast \& Islands.

[14] Card, David, Martin D. Dooley, and A. Abigail Payne. 2010. "School Competition and Efficiency with Publicly Funded Catholic Schools." American Economic Journal: Applied Economics, 2(4): $150-76$.

[15] Card, David and Alan B. Krueger. 1992a. "Does School Quality Matter: Returns to Education and the Characteristics of Public Schools in the United States." Journal of Political Economy, 100(1): 1-40.

[16] Card, David and Alan B. Krueger. 1992b. "School Quality and Black-White Relative Earnings: A Direct Assessment." Quarterly Journal of Economics, 107(1): 151-200.

[17] Carnoy Martin, Frank Adamson, Amita Chudgar, Thomas F. Luschei, and John F. Witte. 2007. Vouchers and Public School Performance. Washington, DC: Economic Policy Institute.

[18] Carter, Samuel C. 2000. "No Excuses: Lessons from 21 High-Performing, High-Poverty Schools." Heritage Foundation.

[19] Chakrabarti, Rajashri. 2008. "Can Increasing Private School Participation and Monetary Loss in a Voucher Program Affect Public School Performance? Evidence from Milwaukee." Journal of Public Economics, 92(5-6):1371-1393.

[20] Coleman, James, Ernest Campbell, Carol Hobson, James McPartland, Alexander Mood, Frederic Weinfeld, and Robert York. 1966. "Equality of Educational Opportunity." Washington, DC: U.S. Government Printing Office.

[21] Couch, Jim F., William F. Shughart, and Al L. Williams. 1993. "Private School Enrollment and Public School Performance." Public Choice, 76(4): 301-312.

[22] Cullen, Julie Berry, Brian A. Jacob, and Steven Levitt. 2005. "The Impact of School Choice on Student Outcomes: An Analysis of the Chicago Public Schools." Journal of Public Economics, 89: 729-760

[23] Cullen, Julie Berry, Brian A. Jacob, and Steven Levitt. 2006. "The Effect of School Choice on Participants: Evidence from Randomized Lotteries." Econometrica, 74(5): 1191-1230.

[24] Curto, Vilsa, and Roland G. Fryer. 2011. "Estimating the Returns to Urban Boarding Schools: Evidence from SEED." NBER Working Paper No. 16746. 
[25] Deming, David J. Forthcoming. "Better Schools, Less Crime?" Quarterly Journal of Economics.

[26] Deming, David J., Justine S. Hastings, Thomas J. Kane, Douglas O. Staiger. 2011. "School Choice, School Quality and Academic Achievement." NBER Working Paper No. 17438.

[27] Dobbie, Will, and Roland G. Fryer. 2011. "Are High-Quality Schools Enough to Increase Achievement among the Poor? Evidence from the Harlem Children's Zone." American Economic Journal: Applied Economics, 3(3): 158-187.

[28] Edmonds, Ronald. 1979. "Effective Schools for the Urban Poor." Educational Leadership, 37(1): $15-24$.

[29] Edmonds, Ronald. 1982. "Programs of School Improvement: An Overview." Educational Leadership, 40(3): 4-11.

[30] Epple, Dennis and Richard E. Romero. 1999. "Competition Between Private and Public Schools, Vouchers, and Peer-Group Effects." American Economic Review, 88(1): 33-62.

[31] Fleischman, H.L., Hopstock, P.J., Pelczar, M.P., and Shelley, B.E. 2010. "Highlights From PISA 2009: Performance of U.S. 15-Year-Old Students in Reading, Mathematics, and Science Literacy in an International Context (NCES 2011-004)." U.S. Department of Education, National Center for Education Statistics. Washington, DC: U.S. Government Printing Office.

[32] Fryer, Roland and Steven D. Levitt. 2004. "Understanding the Black-White Test Score Gap in the First Two Years of School." The Review of Economics and Statistics, 86(2): 447-464.

[33] Fryer, Roland and Steven D. Levitt. 2006. "The Black-White Test Score Gap Through Third Grade." American Law and Economics Review, 8(2): 249-281.

[34] Fryer, Roland. 2011. "Creating "No Excuses" (Traditional) Public Schools: Preliminary Evidence from an Experiment in Houston." NBER Working Paper No. 17494.

[35] Geller, Christopher R., David L. Sjoquist, and Mary Beth Walker. 2006. "The Effect of Private School Competition on Public School Performance in Georgia." Public Finance Review, 34(1): 4-32.

[36] Gleason, Philip, Melissa Clark, Christina Clark Tuttle, Emily Dwoyer, and Marsha Silverberg. 2010. "The Evaluation of Charter School Impacts." National Center for Education Evaluation and Regional Assistance, Institute of Education Sciences, U.S. Department of Education. 
[37] Hanushek, Eric, Steven G. Rivkin, Lori L. Taylor. 1996. "Aggregation and the Estimated Effects of School Resources." The Review of Economics and Statistics, 78(4): 611-627.

[38] Hanushek, Eric A. 1986. "The Economics of Schooling: Production and Efficiency in Public Schools." Journal of Economic Literature, 24(3): 1141-1177.

[39] Hanushek, Eric. 1997. "Assessing the Effects of School Resources on Student Performance: An Update." Educational Evaluation and Policy Analysis, 19(2): 141-164.

[40] Hanushek, Eric. 2009. "Teacher Deselection." In Creating a New Teaching Profession, edited by Dan Goldhaber and Jane Hannaway (eds.), 165-180. Washington, DC: Urban Institute Press.

[41] Hastings, Justine S., Thomas J. Kane, and Douglas O. Staiger. 2006. "Gender and Performance: Evidence from School Assignment by Randomized Lottery." American Economic Review Papers and Proceedings, 96(2): 232-236.

[42] Heckman, James S., Anne Layne-Farrar, and Petra Todd. 1996. "Does Measured School Quality Really Matter? An Examination of the Earnings-Quality Relationship." In Does money matter? The Effect of School Resources on Student Achievement and Adult Success, edited by Gary Burtless, 192-289. Washington, DC: Brookings.

[43] Howell, William G., and Paul E. Peterson. 2002. The Education Gap: Vouchers and Urban Schools. Washington, DC: Brookings Institution Press.

[44] Hoxby, Caroline M. and Sonali Murarka. 2009. "Charter Schools in New York City: Who Enrolls and How They Affect Their Students' Achievement," NBER Working Paper No. 14852.

[45] Hoxby, Caroline M. 1994. "Do Private Schools Provide Competition for Public Schools?" NBER Working Paper No. 4978.

[46] Hoxby, Caroline M. 2000. "Does Competition Among Public Schools Benefit Students and Taxpayers?" American Economic Review, 90(5): 1209-1238.

[47] Hoxby, Caroline M. 2003. "School Choice and School Productivity: Could School Choice be a Tide that Lifts All Boats?" In The Economics of School Choice, ed. Caroline M Hoxby, 287-341. Chicago: The University of Chicago Press.

[48] Hsieh, Chang-Tai, and Miguel Urquiola. 2006. "The Effects of Generalized School Choice on Achievement and Stratification: Evidence from Chile's Voucher Program." Journal of Public Economics, 90(8-9): 1477-1503. 
[49] Jepsen, Christopher. 2002. "The Role of Aggregation in Estimating the Effects of Private School Competition on Student Achievement." Journal of Urban Economics, 52(3): 477-500.

[50] Jepsen, Christopher. 2003. "The Effectiveness of Catholic Primary Schooling." Journal of Human Resources, 38(4): 928-941.

[51] Kane, Thomas J., and Douglas O. Staiger. 2008. "Estimating Teacher Impacts on Student Achievement: An Experimental Evaluation," NBER Working Paper No. 14607.

[52] Krueger Alan B. 2003. "Economic Considerations and Class Size." Economic Journal, 113(485): 34-63.

[53] Krueger Alan B., and Pei Zhu. 2004. "Another Look at the New York City School Voucher Experiment." American Behavioral Scientist, 47(5): 658-698.

[54] Ladd, Helen F. 2002. "School Vouchers: A Critical View." Journal of Economic Perspectives, 16(4): 3-24.

[55] Madden, J. V, D. Lawson, and D. Sweet. 1976. "School Effectiveness Study." Sacramento, CA: State of California Department of Education.

[56] Monroe, Lorraine. 1999. Nothing's impossible: Leadership lessons from inside and outside the classroom. New York: Times Books.

[57] Nechyba, Thomas. 2000. "Mobility, Targeting and Private School Vouchers." American Economic Review, 90(1): 130-146.

[58] Newmark, Craig M. 1995. "Another Look at Whether Private Schools Influence Public School Quality." Public Choice, 82(3-4): 365-373.

[59] Payton, John, Roger P. Weissberg, Joseph A. Durlak, Allison B. Dymnicki, Rebecca D. Taylor, Kriston B. Schellinger, and Molly Pachan. 2008. The positive impact of social and emotional learning for kindergarten to eighth-grade students: Findings from three scientific reviews. Chicago: Collaborative for Academic, Social, and Emotional Learning.

[60] Peterson, Paul E. 2002. "Victory for Vouchers?" Commentary, 114 (2): 46-51.

[61] Phillips, Meredith, James Crouse, and John Ralph. 1998. "Does the Black-White Test Score Gap Widen after Children Enter School?" In The Black-White Test Score Gap. eds. Christopher Jencks and Meredith Phillips, 229âĂŞ272. Washington, DC: The Brookings Institute.

[62] Rivkin, Steven G., Eric A. Hanushek, and John F. Kain. 2005. "Teachers, schools, and academic achievement." Econometrica 73(2): 417-458. 
[63] Rockoff, Jonah E. 2004. "The Impact of Individual Teachers on Student Achievement: Evidence from Panel Data." American Economic Review 94(2): 247-252.

[64] Rockoff, Jonah E., Brian A. Jacob, Thomas J. Kane, Douglas O. Staiger. 2008. "Can You Recognize an Effective Teacher When You Recruit One?" NBER Working Paper No. 14485.

[65] Rothstein, Jesse. 2006a. "Good Principals or Good Peers: Parental Valuation of School Characteristics, Tiebout Equilibrium, and the Incentive Effects of Competition Among Jurisdictions." American Economic Review, 96(4): 1333-1350.

[66] Rothstein, Jesse. 2006b. "Does Competition Among Public Schools Benefit Students and Taxpayers? A Comment on Hoxby (2000)." American Economic Review , 97(5): 2026-2037.

[67] Rouse Cecilia E. 1998. "Private School Vouchers and Student Achievement: An Evaluation of the Milwaukee Parental Choice Program." Quarterly Journal of Economics, 113(2): 553602.

[68] Sander, William. 1999. "Private Schools and Public School Achievement." Journal of Human Resources, 34(4): 697-709.

[69] State of New York, Office of Education Performance Review. 1974. "School Factors and Influencing Reading Achievement: A Case Study of Two Inner City Schools."

[70] Thernstrom, Abigail, and Stephan Thernstrom. 2004. "No Excuses: Closing the Racial Gap in Learning." Simon \& Schuster.

[71] Whitman, David. 2008. "Sweating the Small Stuff: Inner-City Schools and the New Paternalism." Thomas B. Fordham Institute.

[72] Winters, Marcus. Forthcoming. "Measuring the Effect of Charter Schools on Public School Student Achievement in an Urban Environment: Evidence from New York City." Economics of Education Review.

[73] Wolf, Patrick, Babette Gutmann, Michael Puma, Brian Kisida, Lou Rizzo, Nada Eissa, Matthew Carr,Marsha Silverberg. 2010. "Evaluation of the DC Opportunity Scholarship Program." NCEE 2010-4018. U.S. Department of Education. 
Table 1

School Participation

\begin{tabular}{lcccc}
\hline \hline & All & Eligible & Survey & Lottery \\
Charters & Sample & Sample & Sample \\
& $(1)$ & $(2)$ & $(3)$ & $(4)$ \\
\hline Elementary & 68 & 48 & 22 & 13 \\
Middle & 38 & 37 & 13 & 9 \\
\hline \hline
\end{tabular}

Notes: This table reports the number of elementary and middle charter schools in New York City and their participation in the observational and lottery studies. Elementary schools include all schools that have their main admissions lottery in grades PK - 4. Middle schools include all schools that have their main admissions lottery in grades $5-8$. Eligible charters are defined as schools that serve a general student population with at least one tested grade in $2009-2010$. 
Table 2

Characteristics of Charter Schools

\begin{tabular}{|c|c|c|c|c|}
\hline \multirow[b]{3}{*}{ Human Capital } & \multicolumn{2}{|c|}{ Elementary Schools } & \multicolumn{2}{|c|}{ Middle Schools } \\
\hline & Above & Below & Above & Below \\
\hline & Median & Median & Median & Median \\
\hline Frequent Teacher Feedback & 0.83 & 0.60 & 0.83 & 0.14 \\
\hline Teacher Formal Feedback & 3.52 & 2.35 & 3.33 & 1.50 \\
\hline Teacher Informal Feedback & 12.89 & 8.96 & 10.08 & 5.57 \\
\hline Non-Negotiables When Hiring & 1.55 & 1.20 & 1.17 & 1.20 \\
\hline Teacher Tenure & 3.45 & 3.89 & 3.50 & 4.21 \\
\hline Teachers Leaving Involuntarily & 0.09 & 0.07 & 0.07 & 0.14 \\
\hline Total Teacher Hours & 60.25 & 52.50 & 60.00 & 49.71 \\
\hline Teacher Non-Instructional Hours & 2.25 & 2.00 & 5.33 & 2.50 \\
\hline Teacher Responsibilities & 2.17 & 2.60 & 3.33 & 2.00 \\
\hline Max Teacher Pay & 7.89 & 8.13 & 8.39 & 8.68 \\
\hline \multicolumn{5}{|l|}{ Data Driven Instruction } \\
\hline Data Driven Instruction & 0.86 & 0.50 & 1.00 & 0.33 \\
\hline Uses Interim Assessments & 1.00 & 0.90 & 0.83 & 1.00 \\
\hline Number of Interim Assessments & 3.92 & 2.42 & 4.00 & 2.04 \\
\hline Number of Differentiation Strategies & 4.62 & 3.50 & 4.67 & 4.00 \\
\hline Number of Teacher Reports & 4.27 & 3.50 & 3.00 & 2.86 \\
\hline Data Plan in Place & 0.50 & 0.38 & 0.33 & 0.33 \\
\hline Tracking Using Data & 0.45 & 0.20 & 0.67 & 0.57 \\
\hline \multicolumn{5}{|l|}{ Parent Engagement } \\
\hline Academic Feedback & 6.14 & 5.58 & 13.92 & 6.79 \\
\hline Behavior Feedback & 20.67 & 10.60 & 23.00 & 15.25 \\
\hline Regular Feedback & 9.32 & 6.34 & 16.00 & 1.46 \\
\hline \multicolumn{5}{|l|}{ Tutoring } \\
\hline High-Dosage Tutoring & 0.33 & 0.10 & 0.17 & 0.00 \\
\hline Any Tutoring & 0.91 & 0.89 & 1.00 & 0.57 \\
\hline Small Group Tutoring & 0.60 & 0.50 & 0.17 & 0.25 \\
\hline Frequent Tutoring & 0.60 & 0.12 & 0.67 & 0.25 \\
\hline \multicolumn{5}{|l|}{ Instructional Time } \\
\hline$+25 \%$ Increase in Time & 0.67 & 0.00 & 0.67 & 0.57 \\
\hline Instructional Hours & 8.07 & 7.36 & 8.17 & 7.87 \\
\hline Instructional Days & 190.67 & 183.80 & 191.00 & 187.14 \\
\hline Daily Time on Math & 68.30 & 77.11 & 84.33 & 77.40 \\
\hline Daily Time on ELA & 137.86 & 122.86 & 113.00 & 91.90 \\
\hline \multicolumn{5}{|l|}{ Culture and Expectations } \\
\hline High Expectations & 0.58 & 0.10 & 0.50 & 0.43 \\
\hline School-wide Discipline & 0.25 & 0.10 & 0.50 & 0.29 \\
\hline Schools & 12 & 10 & 6 & 7 \\
\hline
\end{tabular}


Table 2

Characteristics of Charter Schools Continued

\begin{tabular}{|c|c|c|c|c|}
\hline \multirow[b]{3}{*}{ Traditional Inputs } & \multicolumn{2}{|c|}{ Elementary Schools } & \multicolumn{2}{|c|}{ Middle Schools } \\
\hline & Above & Below & Above & Below \\
\hline & Median & Median & Median & Median \\
\hline Small Classes & 0.17 & 0.40 & 0.25 & 1.00 \\
\hline High Expenditure & 0.44 & 0.33 & 0.67 & 0.60 \\
\hline High Teachers with MA & 0.33 & 0.50 & 0.50 & 0.83 \\
\hline Low Teachers without Certification & 0.50 & 0.50 & 0.00 & 0.67 \\
\hline \multicolumn{5}{|l|}{ Lesson Plans } \\
\hline Blooms Taxonomy Score & 0.11 & 0.25 & 0.00 & 0.17 \\
\hline Objective Standard & 0.67 & 0.88 & 0.75 & 1.00 \\
\hline Number of Differentiation Strategies & 0.56 & 0.75 & 0.50 & 0.67 \\
\hline Number of Checks For Understanding & 0.00 & 0.00 & 0.00 & 0.00 \\
\hline Thoroughness Index & 4.67 & 5.12 & 5.50 & 6.83 \\
\hline \multicolumn{5}{|l|}{ Other Controls } \\
\hline Wrap-around Service Index & -0.32 & 0.39 & -0.05 & 0.04 \\
\hline Teacher Selection Index & 0.09 & -0.37 & 0.55 & -0.11 \\
\hline No Excuses & 0.60 & 0.25 & 0.80 & 0.29 \\
\hline Schools & 12 & 10 & 6 & 7 \\
\hline
\end{tabular}

Notes: This table reports results from a survey of New York City charter schools with entry in elementary school (PK - 4th) or middle school (5th - 8th) grades. The survey sample excludes schools without a tested grade in 2009 - 2010. 
Table 3

Student Summary Statistics

\begin{tabular}{|c|c|c|c|c|c|c|c|}
\hline & \multirow[b]{2}{*}{ NYC } & \multirow{2}{*}{$\begin{array}{c}\text { Eligible } \\
\text { Charters }\end{array}$} & \multirow{2}{*}{$\begin{array}{c}\text { Survey } \\
\text { Charters }\end{array}$} & \multirow{2}{*}{$\begin{array}{l}\text { Lottery } \\
\text { Charters }\end{array}$} & \multicolumn{3}{|c|}{ Lottery Applicants } \\
\hline & & & & & Winners & Losers & Difference \\
\hline & \multicolumn{7}{|c|}{ Panel A. Elementary Schools (3rd - 5th Grades) } \\
\hline Male & 0.51 & 0.49 & 0.49 & 0.52 & 0.52 & 0.55 & 0.00 \\
\hline White & 0.15 & 0.03 & 0.02 & 0.00 & 0.01 & 0.01 & -0.00 \\
\hline Black & 0.33 & 0.67 & 0.64 & 0.71 & 0.70 & 0.65 & 0.01 \\
\hline Hispanic & 0.39 & 0.28 & 0.31 & 0.27 & 0.27 & 0.32 & -0.02 \\
\hline Asian & 0.13 & 0.02 & 0.02 & 0.00 & 0.01 & 0.01 & -0.00 \\
\hline Free Lunch & 0.84 & 0.82 & 0.84 & 0.84 & 0.86 & 0.89 & $-0.04^{* * *}$ \\
\hline Special Education & 0.09 & 0.03 & 0.05 & 0.03 & 0.05 & 0.07 & $-0.02^{* *}$ \\
\hline LEP & 0.11 & 0.04 & 0.04 & 0.03 & 0.04 & 0.07 & -0.01 \\
\hline Years in Charter & 0.06 & 2.19 & 1.91 & 2.49 & 1.83 & 0.91 & $0.68^{* * *}$ \\
\hline \multirow[t]{2}{*}{ Observations } & 678708 & 18872 & 8109 & 1986 & 1769 & 3448 & \\
\hline & \multicolumn{7}{|c|}{ Panel B. Middle Schools (5th - 8th Grades) } \\
\hline Male & 0.51 & 0.49 & 0.50 & 0.48 & 0.48 & 0.51 & -0.01 \\
\hline White & 0.14 & 0.03 & 0.03 & 0.02 & 0.03 & 0.02 & 0.00 \\
\hline Black & 0.34 & 0.64 & 0.62 & 0.66 & 0.62 & 0.63 & 0.02 \\
\hline Hispanic & 0.39 & 0.30 & 0.33 & 0.31 & 0.33 & 0.33 & -0.02 \\
\hline Asian & 0.13 & 0.02 & 0.02 & 0.01 & 0.01 & 0.02 & -0.01 \\
\hline Free Lunch & 0.84 & 0.83 & 0.84 & 0.85 & 0.87 & 0.88 & -0.00 \\
\hline Special Education & 0.09 & 0.04 & 0.06 & 0.07 & 0.09 & 0.10 & 0.01 \\
\hline LEP & 0.09 & 0.04 & 0.04 & 0.05 & 0.05 & 0.06 & $-0.01^{*}$ \\
\hline Baseline Math & 0.02 & -0.06 & -0.18 & -0.29 & -0.25 & -0.21 & -0.04 \\
\hline Baseline ELA & 0.01 & -0.05 & -0.13 & -0.19 & -0.15 & -0.14 & 0.01 \\
\hline Years in Charter & 0.05 & 2.38 & 2.16 & 1.84 & 1.19 & 0.60 & $0.29^{* * *}$ \\
\hline Observations & 778929 & 17263 & 6491 & 1545 & 1608 & 3025 & \\
\hline
\end{tabular}

Notes: This table reports descriptive statistics for the sample of public school students, the sample of students in eligible charter schools, the sample of students in charter schools in the observational study, and the sample of students in the lottery study. The sample is restricted to students in grades 3 - 8 between 2003 - 2004 and 2009 - 2010 with at least one follow up test score. The final column reports coefficients from regressions of an indicator variable equal to one if the student won an admissions lottery on the variable indicated in each row and lottery risk sets. ${ }^{* * *}=$ significant at 1 percent level, ${ }^{* *}=$ significant at 5 percent level, ${ }^{*}=$ significant at 10 percent level. 
Table 4

The Effect of Attending a Charter School on Test Scores

\begin{tabular}{ccccccc}
\hline \hline & & Reduced & First & & Lottery & Survey \\
Form & Stage & 2SLS & OLS & OLS \\
Level & Subject & $(1)$ & $(2)$ & $(3)$ & $(4)$ & $(5)$ \\
\hline \multirow{6}{*}{ Math } & $0.119^{* * *}$ & $0.755^{* * *}$ & $0.158^{* * *}$ & $0.054^{* * *}$ & $0.041^{* * *}$ \\
& $(0.029)$ & $(0.054)$ & $(0.038)$ & $(0.004)$ & $(0.003)$ \\
& 9706 & 9706 & 9706 & 666928 & 666928 \\
& & $0.056^{* *}$ & $0.755^{* * *}$ & $0.074^{* *}$ & $0.050^{* * *}$ & $0.036^{* * *}$ \\
& $(0.027)$ & $(0.054)$ & $(0.036)$ & $(0.003)$ & $(0.003)$ \\
& 9706 & 9706 & 9706 & 666928 & 666928 \\
& & $9.064^{* * *}$ & $0.403^{* * *}$ & $0.159^{* * *}$ & $0.051^{* * *}$ & $0.029^{* * *}$ \\
& $(0.015)$ & $(0.024)$ & $(0.037)$ & $(0.004)$ & $(0.002)$ \\
& 11712 & 11712 & 11712 & 1061829 & 1061829 \\
& $0.023^{*}$ & $0.404^{* * *}$ & $0.057^{*}$ & $0.013^{* * *}$ & $0.015^{* * *}$ \\
& $(0.014)$ & $(0.024)$ & $(0.034)$ & $(0.004)$ & $(0.002)$ \\
& 11712 & 11712 & 11712 & 1061829 & 1061829 \\
\hline \hline
\end{tabular}

Notes: This table reports reduced form, first stage, and two-stage least squares results for the lottery study (Columns 1 - 3) and observational estimates for the survey study (Columns 4 - 5). The lottery sample is restricted to students in an elementary or middle school charter school lottery, excluding students with sibling preference. All lottery specifications control for lottery risk set, race, sex, free lunch eligibility, grade, and year. All observational specifications include match cell, race, sex, free lunch eligibility, grade, and year. Middle school specifications also include baseline test scores. All specifications cluster standard errors at the student level. ${ }^{* * *}=$ significant at 1 percent level, ${ }^{* *}=$ significant at 5 percent level, ${ }^{*}=$ significant at 10 percent level. 
Table 5

The Correlation Between Traditional Resource Inputs and School Effectiveness

\begin{tabular}{|c|c|c|c|c|c|}
\hline \multirow[b]{3}{*}{ Class Size } & \multicolumn{5}{|c|}{ Panel A: Math Results } \\
\hline & $(1)$ & $(2)$ & $(3)$ & $(4)$ & $(5)$ \\
\hline & $\begin{array}{c}-0.041 \\
(0.029)\end{array}$ & & & & \\
\hline Per Pupil Expenditure & & $\begin{array}{c}0.003 \\
(0.028)\end{array}$ & & & \\
\hline Teachers with No Certification & & & $\begin{array}{r}-0.043^{*} \\
(0.022)\end{array}$ & & \\
\hline Teachers with MA & & & & $\begin{array}{r}-0.038 \\
(0.026)\end{array}$ & \\
\hline Index & & & & & $\begin{array}{c}-0.029^{* * *} \\
(0.011)\end{array}$ \\
\hline$R^{2}$ & 0.060 & 0.001 & 0.078 & 0.059 & 0.136 \\
\hline \multirow[t]{3}{*}{ Observations } & 35 & 35 & 35 & 35 & 35 \\
\hline & \multicolumn{5}{|c|}{ Panel B: ELA Results } \\
\hline & $(6)$ & $(7)$ & $(8)$ & $(9)$ & $(10)$ \\
\hline Class Size & $\begin{array}{c}-0.027 \\
(0.021)\end{array}$ & & & & \\
\hline Per Pupil Expenditure & & $\begin{array}{c}-0.001 \\
(0.020)\end{array}$ & & & \\
\hline Teachers with No Certification & & & $\begin{array}{c}-0.023 \\
(0.018)\end{array}$ & & \\
\hline Teachers with MA & & & & $\begin{array}{r}-0.034^{*} \\
(0.019)\end{array}$ & \\
\hline Index & & & & & $\begin{array}{c}-0.021^{*} \\
(0.011) \\
\end{array}$ \\
\hline$R^{2}$ & 0.117 & 0.071 & 0.112 & 0.158 & 0.204 \\
\hline Observations & 35 & 35 & 35 & 35 & 35 \\
\hline
\end{tabular}

Notes: This table reports regressions of school-specific treatment effects on school characteristics. The sample includes all schools with at least one tested grade that completed the charter survey. Each independent variable is an indicator for being above the median in that domain. The index is a sum of the dichotomous measures standardized to have a mean of zero and standard deviation of one. Regressions weight by the inverse of the standard error of the estimated school impact. Standard errors are clustered at the school level. ${ }^{* * *}=$ significant at 1 percent level, ${ }^{* *}=$ significant at 5 percent level, ${ }^{*}=$ significant at 10 percent level. 
Table 6

The Correlation Between Non-Traditional (i.e. "Within the School")

Inputs and School Effectiveness

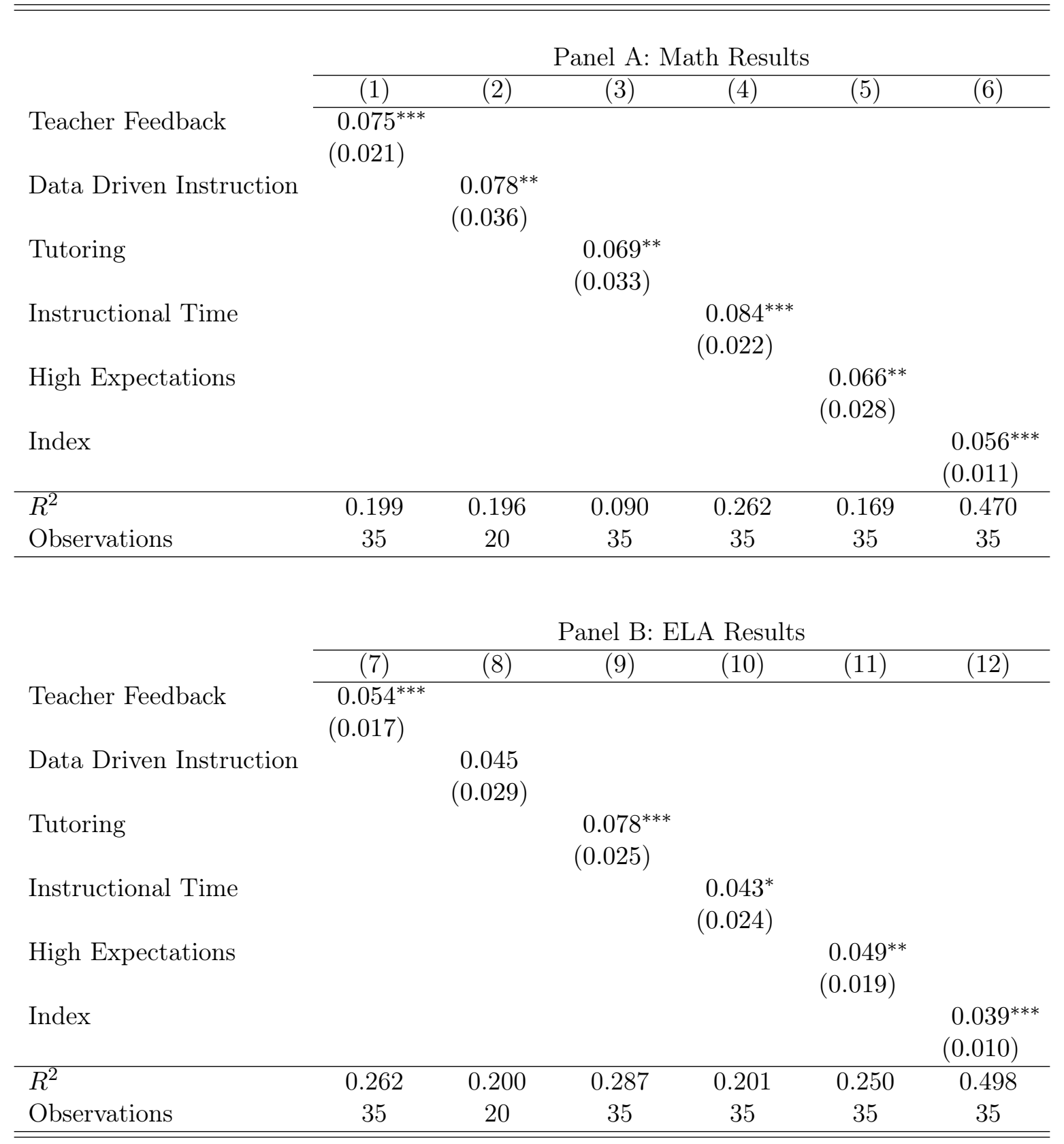

Notes: This table reports regressions of school-specific treatment effects on school characteristics. The sample includes all schools with at least one tested grade that completed the charter survey. Regressions weight by the inverse of the standard error of the estimated school impact. ${ }^{* * *}=$ significant at 1 percent level, ${ }^{* *}=$ significant at 5 percent level, ${ }^{*}=$ significant at 10 percent level. 
Table 7

The Partial Correlation of Each Non-Traditional Input

\begin{tabular}{|c|c|c|c|c|c|}
\hline \multirow[b]{3}{*}{ Teacher Feedback } & \multicolumn{5}{|c|}{ Panel A: Math Results } \\
\hline & $(1)$ & $(2)$ & $(3)$ & $(4)$ & $(5)$ \\
\hline & $\begin{array}{r}0.038^{*} \\
(0.022)\end{array}$ & & & & \\
\hline Data Driven Instruction & & $\begin{array}{c}0.051^{* *} \\
(0.022)\end{array}$ & & & \\
\hline Tutoring & & & $\begin{array}{c}0.044^{*} \\
(0.026)\end{array}$ & & \\
\hline Instructional Time & & & & $\begin{array}{l}0.059^{* * *} \\
(0.015)\end{array}$ & \\
\hline High Expectations & & & & & $\begin{array}{c}0.014 \\
(0.011)\end{array}$ \\
\hline Index & $\begin{array}{l}0.046^{* * *} \\
(0.012)\end{array}$ & $\begin{array}{l}0.051^{* * *} \\
(0.010)\end{array}$ & $\begin{array}{l}0.052^{* * *} \\
(0.011)\end{array}$ & $\begin{array}{l}0.039^{* * *} \\
(0.009)\end{array}$ & $\begin{array}{l}0.054^{* * *} \\
(0.010)\end{array}$ \\
\hline$R^{2}$ & 0.471 & 0.479 & 0.470 & 0.482 & 0.494 \\
\hline Observations & 35 & 35 & 35 & 35 & 35 \\
\hline & & Panel & B: ELA R & esults & \\
\hline & $(6)$ & $(7)$ & $(8)$ & $(9)$ & $(10)$ \\
\hline Teacher Feedback & $\begin{array}{c}0.028^{*} \\
(0.015)\end{array}$ & & & & \\
\hline Data Driven Instruction & & $\begin{array}{c}0.025 \\
(0.020)\end{array}$ & & & \\
\hline Tutoring & & & $\begin{array}{l}0.064^{* * *} \\
(0.021)\end{array}$ & & \\
\hline Instructional Time & & & & $\begin{array}{c}0.020 \\
(0.020)\end{array}$ & \\
\hline High Expectations & & & & & $\begin{array}{c}0.015 \\
(0.012)\end{array}$ \\
\hline Index & $\begin{array}{l}0.031^{* * *} \\
(0.009)\end{array}$ & $\begin{array}{l}0.035^{* * *} \\
(0.009)\end{array}$ & $\begin{array}{l}0.031^{* * *} \\
(0.009)\end{array}$ & $\begin{array}{l}0.033^{* * *} \\
(0.011)\end{array}$ & $\begin{array}{l}0.035^{* * *} \\
(0.010)\end{array}$ \\
\hline$R^{2}$ & 0.498 & 0.499 & 0.544 & 0.503 & 0.510 \\
\hline Observations & 35 & 35 & 35 & 35 & 35 \\
\hline
\end{tabular}

Notes: This table reports regressions of school-specific treatment effects on school characteristics. The sample includes all schools with at least one tested grade that completed the charter survey. Regressions weight by the inverse of the standard error of the estimated school impact. $* * *=$ significant at 1 percent level, $* *=$ significant at 5 percent level, $*=$ significant at 10 percent level. 


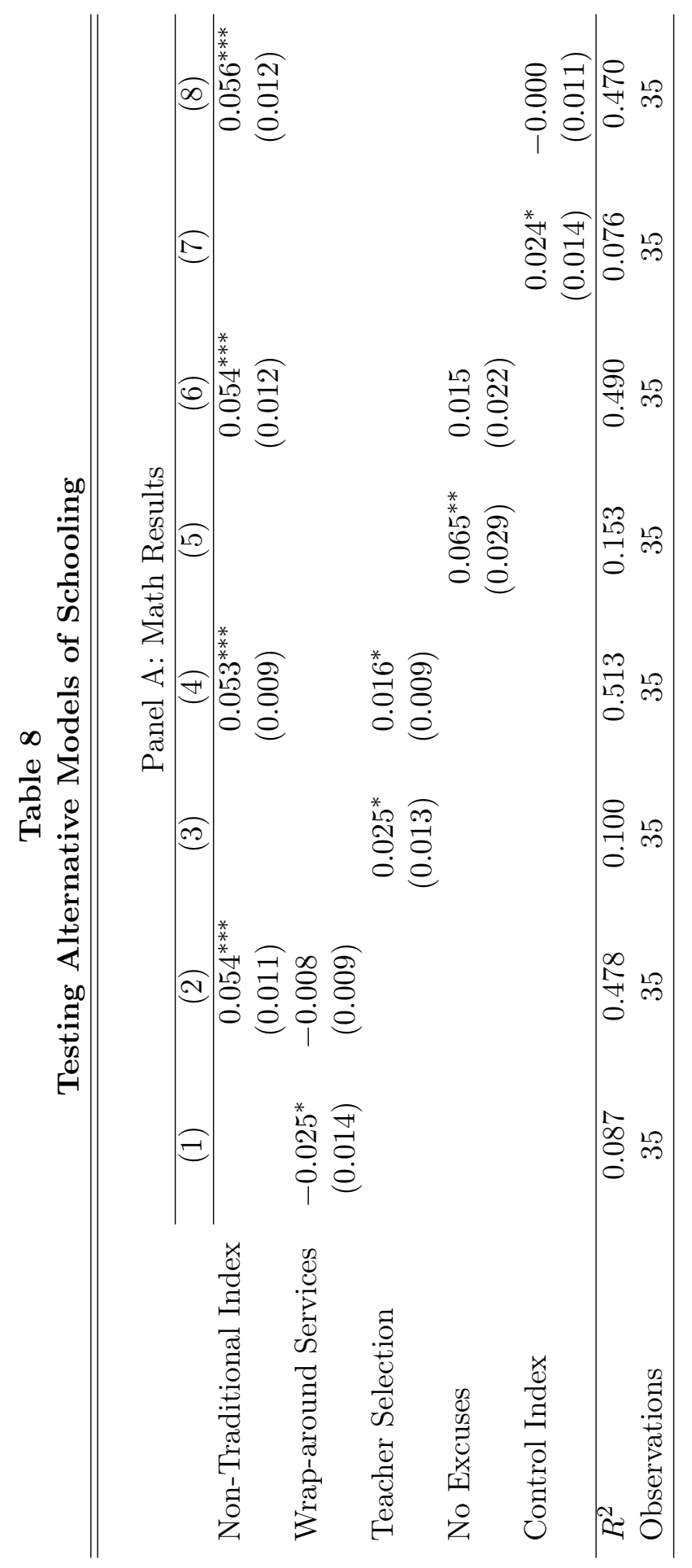




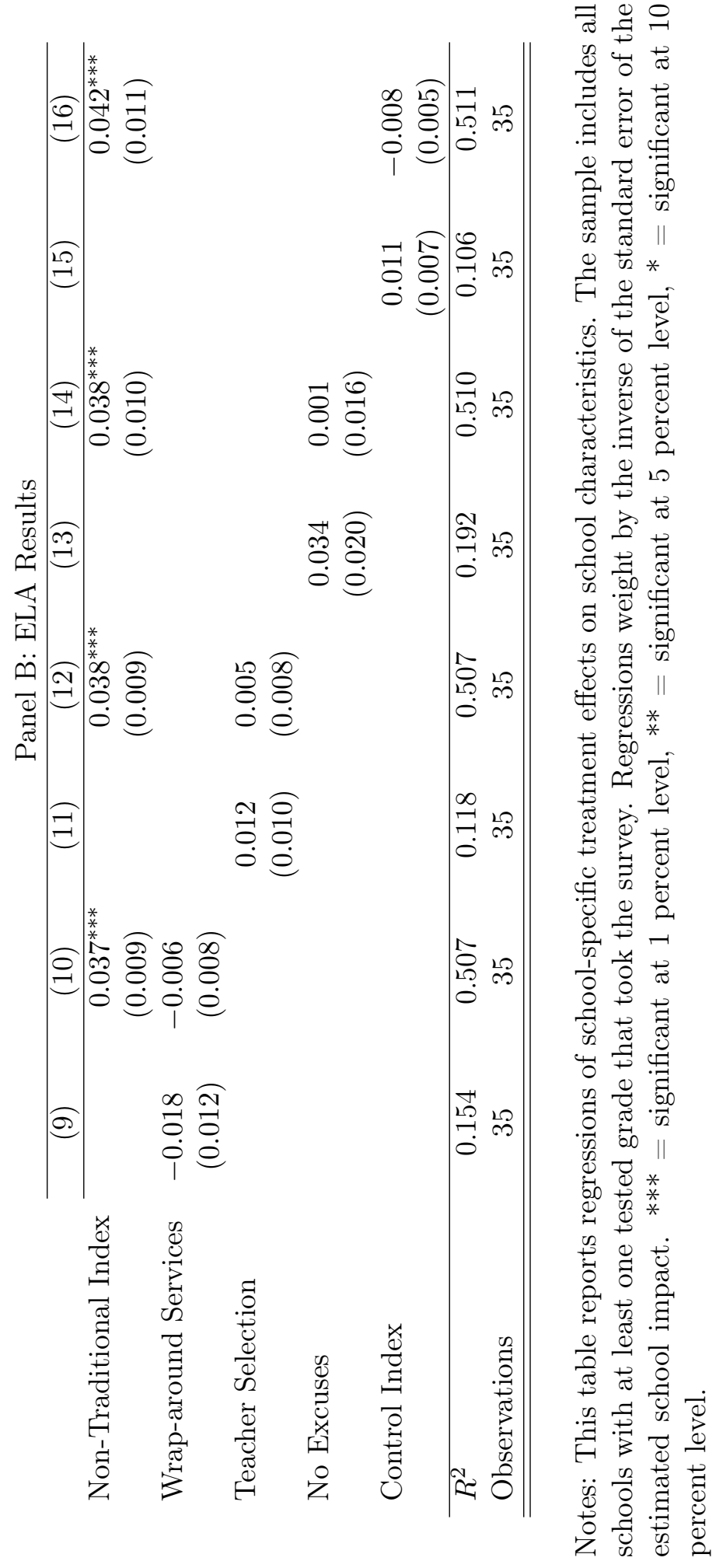


Table 9

Out of Sample Test of Non-Traditional Inputs

\begin{tabular}{|c|c|c|c|c|c|}
\hline \multirow[b]{3}{*}{ Teacher Feedback } & \multicolumn{5}{|c|}{ Panel A: Math Results } \\
\hline & $(1)$ & $(2)$ & $(3)$ & $(4)$ & $(5)$ \\
\hline & $\begin{array}{c}0.027 \\
(0.022)\end{array}$ & & & & \\
\hline Data Driven Instruction & & $\begin{array}{r}-0.004 \\
(0.026)\end{array}$ & & & \\
\hline Instructional Time & & & $\begin{array}{c}0.056^{* *} \\
(0.023)\end{array}$ & & \\
\hline High Expectations & & & & $\begin{array}{l}0.070^{* * *} \\
(0.025)\end{array}$ & \\
\hline Index & & & & & $\begin{array}{c}0.025^{* *} \\
(0.010)\end{array}$ \\
\hline$R^{2}$ & 0.017 & 0.000 & 0.097 & 0.118 & 0.069 \\
\hline \multirow[t]{3}{*}{ Observations } & 56 & 56 & 49 & 52 & 56 \\
\hline & \multicolumn{5}{|c|}{ Panel B: ELA Results } \\
\hline & $(6)$ & $(7)$ & $(8)$ & $(9)$ & $(10)$ \\
\hline Teacher Feedback & $\begin{array}{c}0.008 \\
(0.014)\end{array}$ & & & & \\
\hline Data Driven Instruction & & $\begin{array}{c}-0.009 \\
(0.015)\end{array}$ & & & \\
\hline Instructional Time & & & $\begin{array}{c}0.018 \\
(0.016)\end{array}$ & & \\
\hline High Expectations & & & & $\begin{array}{l}0.051^{* * *} \\
(0.018)\end{array}$ & \\
\hline Index & & & & & $\begin{array}{c}0.011^{*} \\
(0.006)\end{array}$ \\
\hline$R^{2}$ & 0.004 & 0.005 & 0.026 & 0.164 & 0.037 \\
\hline Observations & 56 & 56 & 49 & 52 & 56 \\
\hline
\end{tabular}

Notes: This table reports regressions of school-specific treatment effects on school characteristics. The sample includes all schools with at least one tested grade with available site visit data. Regressions weight by the inverse of the standard error of the estimated school impact. ${ }^{* * *}=$ significant at 1 percent level, ${ }^{* *}=$ significant at 5 percent level, ${ }^{*}=$ significant at 10 percent level. 


\section{Figure 1}

\section{Lottery and Observational Estimates}
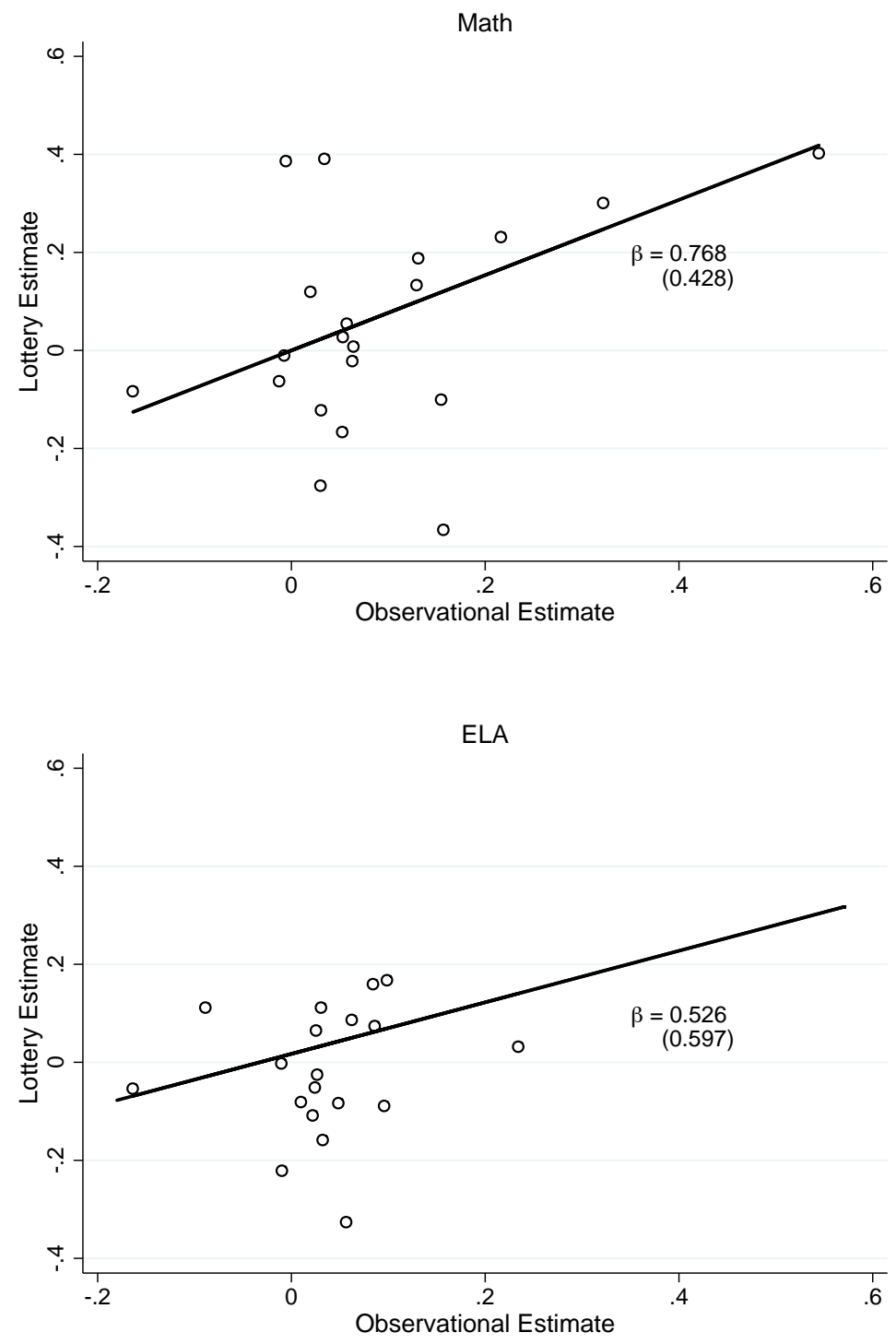

Notes: This figure reports school-specific treatment estimates using the lottery and observational designs. The lottery sample is restricted to students in an elementary or middle school charter school lottery, excluding students with sibling preference. All lottery specifications control for lottery risk set, race, sex, free lunch eligibility, grade, and year. All observational specifications include match cell, race, sex, free lunch eligibility, grade, and year. Middle school specifications also include baseline test scores. 
Appendix Table 1

Charter Schools in Survey Sample

\begin{tabular}{|c|c|c|c|c|c|}
\hline & $\begin{array}{c}2010-2011 \\
\text { Grades }\end{array}$ & $\begin{array}{c}\text { Year } \\
\text { Opened }\end{array}$ & $\begin{array}{c}\text { Years in } \\
\text { lottery study }\end{array}$ & Survey & Video \\
\hline \multicolumn{6}{|c|}{ Panel A: Elementary Schools (3rd - 5th Grades) } \\
\hline Amber Charter School & $K-5$ & 2000 & $2005-2006$ & Yes & Yes \\
\hline Bronx Academy of Promise & $\mathrm{K}-3$ & 2008 & & Yes & No \\
\hline Bronx Charter School for Children & $K-5$ & 2004 & 2006 & Yes & Yes \\
\hline Bronx Charter School for the Arts & $K-6$ & 2003 & & Yes & Yes \\
\hline Brooklyn Ascend Charter School & $\mathrm{K}-4$ & 2008 & 2008 & Yes & Yes \\
\hline Excellence Boys Charter School & $\mathrm{K}-7$ & 2004 & $2003-2006$ & Yes & Yes \\
\hline Explore Charter School & $K-8$ & 2000 & $2005-2006$ & Yes & Yes \\
\hline Family Life Academy Charter School & $K-8$ & 2001 & & Yes & No \\
\hline Future Leaders Institute Charter School & $\mathrm{K}-5$ & 2005 & & No & Yes \\
\hline Girls Preparatory Charter School & $\mathrm{K}-6$ & 2005 & & Yes & Yes \\
\hline Grand Concourse Academy Charter School & $K-5$ & 2004 & & Yes & Yes \\
\hline Harbor Science and Arts Charter School & $1-8$ & 2002 & 2007 & Yes & Yes \\
\hline Harlem Children's Zone Promise Academy & $\mathrm{K}-5$ & 2004 & $2004-2006$ & Yes & Yes \\
\hline Harlem Children's Zone Promise Academy II & $\mathrm{K}-6$ & 2005 & $2005-2006$ & Yes & Yes \\
\hline Harlem Link Charter School & $\mathrm{K}-5$ & 2005 & $2005-2009$ & Yes & Yes \\
\hline Harlem Success Academy Charter School & $\mathrm{K}-5$ & 2006 & $2006-2008$ & Yes & Yes \\
\hline Hyde Leadership Charter School Bronx & $\mathrm{K}-5$ & 2009 & 2006 & Yes & Yes \\
\hline Manhattan Charter School & $K-5$ & 2005 & 2008 & Yes & No \\
\hline Peninsula Preparatory Academy & $\mathrm{K}-5$ & 2004 & 2009 & Yes & Yes \\
\hline Renaissance Charter School & $\mathrm{K}-5$ & 2000 & & Yes & Yes \\
\hline Sisulu-Walker Charter School of Harlem & $\mathrm{K}-5$ & 1999 & & Yes & Yes \\
\hline South Bronx Classical Charter School & $K-5$ & 2006 & & Yes & Yes \\
\hline South Bronx Int. Cultures and the Arts & $\mathrm{K}-5$ & 2005 & & Yes & No \\
\hline \multicolumn{6}{|c|}{ Panel B: Middle Schools (5th - 8th Grades) } \\
\hline Bronx Preparatory Charter School & $5-8$ & 2000 & $2008-2009$ & Yes & Yes \\
\hline Coney Island Preparatory Charter School & $5-6$ & 2009 & $2009-2010$ & Yes & Yes \\
\hline Democracy Preparatory Charter School & $6-10$ & 2006 & $2006-2009$ & Yes & Yes \\
\hline Equality Charter School & $6-8$ & 2009 & 2009 & Yes & Yes \\
\hline Explore Charter School & $6-8$ & 2000 & & Yes & Yes \\
\hline Harbor Science and Arts Charter School & $1-8$ & 2002 & 2007 & Yes & Yes \\
\hline Harlem Children's Zone Promise Academy & $6-8$ & 2004 & $2005-2008$ & Yes & Yes \\
\hline Hyde Leadership Charter School Bronx & $6-10$ & 2009 & $2006-2007$ & Yes & Yes \\
\hline KIPP Infinity & $5-8$ & 2005 & & Yes & No \\
\hline Opportunity Charter School & $6-12$ & 2004 & $2008-2009$ & Yes & Yes \\
\hline Renaissance Charter School & $6-8$ & 2000 & & Yes & Yes \\
\hline St. HOPE Leadership Academy & $5-8$ & 2008 & & Yes & Yes \\
\hline Summit Academy Charter School & $6-7$ & 2009 & 2009 & Yes & Yes \\
\hline
\end{tabular}

Notes: This table lists all New York City charter schools participating in the survey study. Elementary schools include all schools that have their main admissions lottery in grades PK - 4. Middle schools include all schools that have their main admissions lottery in grades $5-8$. Eligible charters serve a general student population with at least one tested grade in $2009-2010$. 


\begin{tabular}{|c|c|c|c|c|c|}
\hline \multirow[t]{3}{*}{ The Correlation } & $\begin{array}{l}\text { Appenc } \\
\text { Between } \\
\text { Effective }\end{array}$ & $\begin{array}{l}\text { Table } \\
\text { raditio } \\
\text { ess: Lot }\end{array}$ & $\begin{array}{l}\text { Resour } \\
\text { ry Estim }\end{array}$ & $\begin{array}{l}\text { Inputs } \\
\text { es }\end{array}$ & \\
\hline & \multicolumn{5}{|c|}{ Panel A: Math Results } \\
\hline & $(1)$ & $(2)$ & $(3)$ & $(4)$ & $(5)$ \\
\hline Class Size & $\begin{array}{r}-0.142 \\
(0.096)\end{array}$ & & & & \\
\hline Per Pupil Expenditures & & $\begin{array}{c}0.073 \\
(0.096)\end{array}$ & & & \\
\hline Teachers with No Certification & & & $\begin{array}{l}-0.118 \\
(0.082)\end{array}$ & & \\
\hline Teachers with MA & & & & $\begin{array}{c}-0.068 \\
(0.061)\end{array}$ & \\
\hline Index & & & & & $\begin{array}{c}-0.053 \\
(0.033)\end{array}$ \\
\hline$R^{2}$ & 0.106 & 0.032 & 0.085 & 0.020 & 0.088 \\
\hline \multirow[t]{3}{*}{ Observations } & 22 & 22 & 22 & 22 & 22 \\
\hline & \multicolumn{5}{|c|}{ Panel B: ELA Results } \\
\hline & $(6)$ & $(7)$ & $(8)$ & $(9)$ & $(10)$ \\
\hline Class Size & $\begin{array}{c}-0.097 \\
(0.094)\end{array}$ & & & & \\
\hline Per Pupil Expenditures & & $\begin{array}{c}0.015 \\
(0.090)\end{array}$ & & & \\
\hline Teachers with No Certification & & & $\begin{array}{r}-0.104 \\
(0.064)\end{array}$ & & \\
\hline Teachers with MA & & & & $\begin{array}{c}0.010 \\
(0.075)\end{array}$ & \\
\hline Index & & & & & $\begin{array}{c}-0.043^{* *} \\
(0.018)\end{array}$ \\
\hline$R^{2}$ & 0.054 & 0.002 & 0.073 & 0.001 & 0.060 \\
\hline Observations & 22 & 22 & 22 & 22 & 22 \\
\hline
\end{tabular}

Notes: This table reports regressions of school-specific treatment effects on school characteristics. The sample includes all schools with at least one tested grade that completed the charter survey. Regressions weight by the inverse of the standard error of the estimated school impact. *** $=$ significant at 1 percent level, ${ }^{* *}=$ significant at 5 percent level, $*=$ significant at 10 percent level. 
Appendix Table 3

The Correlation Between Non-Traditional (i.e. "Within the School")

Inputs and School Effectiveness: Lottery Estimates

\begin{tabular}{|c|c|c|c|c|c|c|}
\hline \multirow[b]{3}{*}{ Teacher Feedback } & \multicolumn{6}{|c|}{ Panel A: Math Results } \\
\hline & $(1)$ & $(2)$ & $(3)$ & $(4)$ & $(5)$ & $(6)$ \\
\hline & $\begin{array}{c}0.170^{* *} \\
(0.067)\end{array}$ & & & & & \\
\hline Data Driven Instruction & & $\begin{array}{c}0.134^{*} \\
(0.065)\end{array}$ & & & & \\
\hline High Quality Tutoring & & & $\begin{array}{c}0.079 \\
(0.151)\end{array}$ & & & \\
\hline Instructional Time & & \multicolumn{5}{|c|}{$\begin{array}{c}0.079 \\
(0.064)\end{array}$} \\
\hline High Expectations & & & & & $\begin{array}{l}0.153^{* * *} \\
(0.055)\end{array}$ & \\
\hline Index & & & & & & $\begin{array}{l}0.088^{* * *} \\
(0.023)\end{array}$ \\
\hline$R^{2}$ & 0.154 & 0.137 & 0.012 & 0.046 & 0.138 & 0.184 \\
\hline Observations & 22 & 14 & 22 & 22 & 22 & 22 \\
\hline & \multicolumn{6}{|c|}{ Panel B: ELA Results } \\
\hline & $(7)$ & (8) & $(9)$ & $(10)$ & $(11)$ & $(12)$ \\
\hline Teacher Feedback & $\begin{array}{c}0.078 \\
(0.050)\end{array}$ & & & & & \\
\hline Data Driven Instruction & & $\begin{array}{l}0.173^{* * *} \\
(0.046)\end{array}$ & & & & \\
\hline High Quality Tutoring & & & $\begin{array}{c}0.114 \\
(0.222)\end{array}$ & & & \\
\hline Instructional Time & & & & $\begin{array}{c}0.042 \\
(0.049)\end{array}$ & & \\
\hline High Expectations & & & & & $\begin{array}{c}0.095^{* *} \\
(0.044)\end{array}$ & \\
\hline Index & & & & & & $\begin{array}{l}0.057^{* * *} \\
(0.019)\end{array}$ \\
\hline$R^{2}$ & 0.037 & 0.344 & 0.018 & 0.014 & 0.058 & 0.088 \\
\hline Observations & 22 & 14 & 22 & 22 & 22 & 22 \\
\hline
\end{tabular}

Notes: This table reports regressions of school-specific treatment effects on school characteristics. The sample includes all schools with at least one tested grade that completed the charter survey. Regressions weight by the inverse of the standard error of the estimated school impact. ${ }^{* * *}=$ significant at 1 percent level, ${ }^{* *}=$ significant at 5 percent level, ${ }^{*}=$ significant at 10 percent level. 


\section{Appendix Table 4 \\ The Partial Correlation of Each Non-Traditional Input: \\ Lottery Estimates}

\begin{tabular}{|c|c|c|c|c|c|}
\hline \multirow[b]{3}{*}{ Teacher Feedback } & \multicolumn{5}{|c|}{ Panel A: Math Results } \\
\hline & $(1)$ & $(2)$ & $(3)$ & $(4)$ & $(5)$ \\
\hline & $\begin{array}{c}0.116 \\
(0.087)\end{array}$ & & & & \\
\hline Data Driven Instruction & & $\begin{array}{c}0.111 \\
(0.088)\end{array}$ & & & \\
\hline High Quality Tutoring & & & $\begin{array}{c}0.041 \\
(0.157)\end{array}$ & & \\
\hline Instructional Time & & & & $\begin{array}{c}-0.053 \\
(0.072)\end{array}$ & \\
\hline High Expectations & & & & & $\begin{array}{c}0.094 \\
(0.098)\end{array}$ \\
\hline Index & $\begin{array}{c}0.050 \\
(0.029)\end{array}$ & $\begin{array}{c}0.063^{* *} \\
(0.028)\end{array}$ & $\begin{array}{l}0.082^{\text {*** }} \\
(0.021)\end{array}$ & $\begin{array}{l}0.126^{* * *} \\
(0.034)\end{array}$ & $\begin{array}{c}0.056 \\
(0.050)\end{array}$ \\
\hline$R^{2}$ & 0.196 & 0.201 & 0.184 & 0.246 & 0.188 \\
\hline \multirow[t]{3}{*}{ Observations } & 22 & 22 & 22 & 22 & 22 \\
\hline & \multicolumn{5}{|c|}{ Panel B: ELA Results } \\
\hline & $(6)$ & $(7)$ & $(8)$ & $(9)$ & $(10)$ \\
\hline Teacher Feedback & $\begin{array}{c}0.024 \\
(0.056)\end{array}$ & & & & \\
\hline Data Driven Instruction & & $\begin{array}{c}0.147^{* *} \\
(0.056)\end{array}$ & & & \\
\hline High Quality Tutoring & & & $\begin{array}{c}0.080 \\
(0.241)\end{array}$ & & \\
\hline Instructional Time & & & & $\begin{array}{r}-0.070 \\
(0.066)\end{array}$ & \\
\hline High Expectations & & & & & $\begin{array}{c}0.048 \\
(0.056)\end{array}$ \\
\hline Index & $\begin{array}{c}0.051^{* *} \\
(0.019)\end{array}$ & $\begin{array}{c}0.027 \\
(0.019)\end{array}$ & $\begin{array}{c}0.050^{* *} \\
(0.023)\end{array}$ & $\begin{array}{l}0.102^{* * *} \\
(0.032)\end{array}$ & $\begin{array}{c}0.042 \\
(0.025)\end{array}$ \\
\hline$R^{2}$ & 0.090 & 0.137 & 0.090 & 0.148 & 0.089 \\
\hline Observations & 22 & 22 & 22 & 22 & 22 \\
\hline
\end{tabular}

Notes: This table reports regressions of school-specific treatment effects on school characteristics. The sample includes all schools with at least one tested grade that completed the charter survey. Regressions weight by the inverse of the standard error of the estimated school impact. ${ }^{* * *}=$ significant at 1 percent level, ${ }^{* *}=$ significant at 5 percent level, ${ }^{*}=$ significant at 10 percent level. 


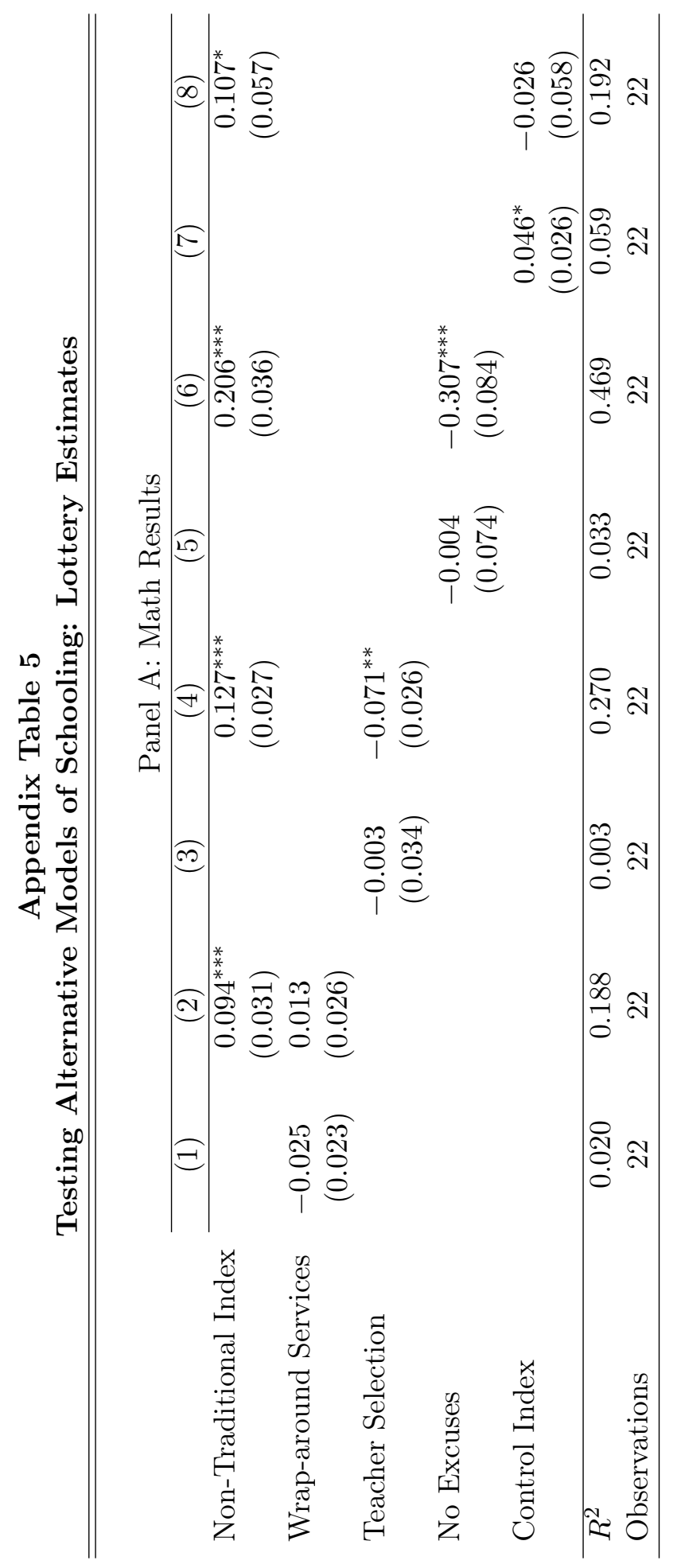




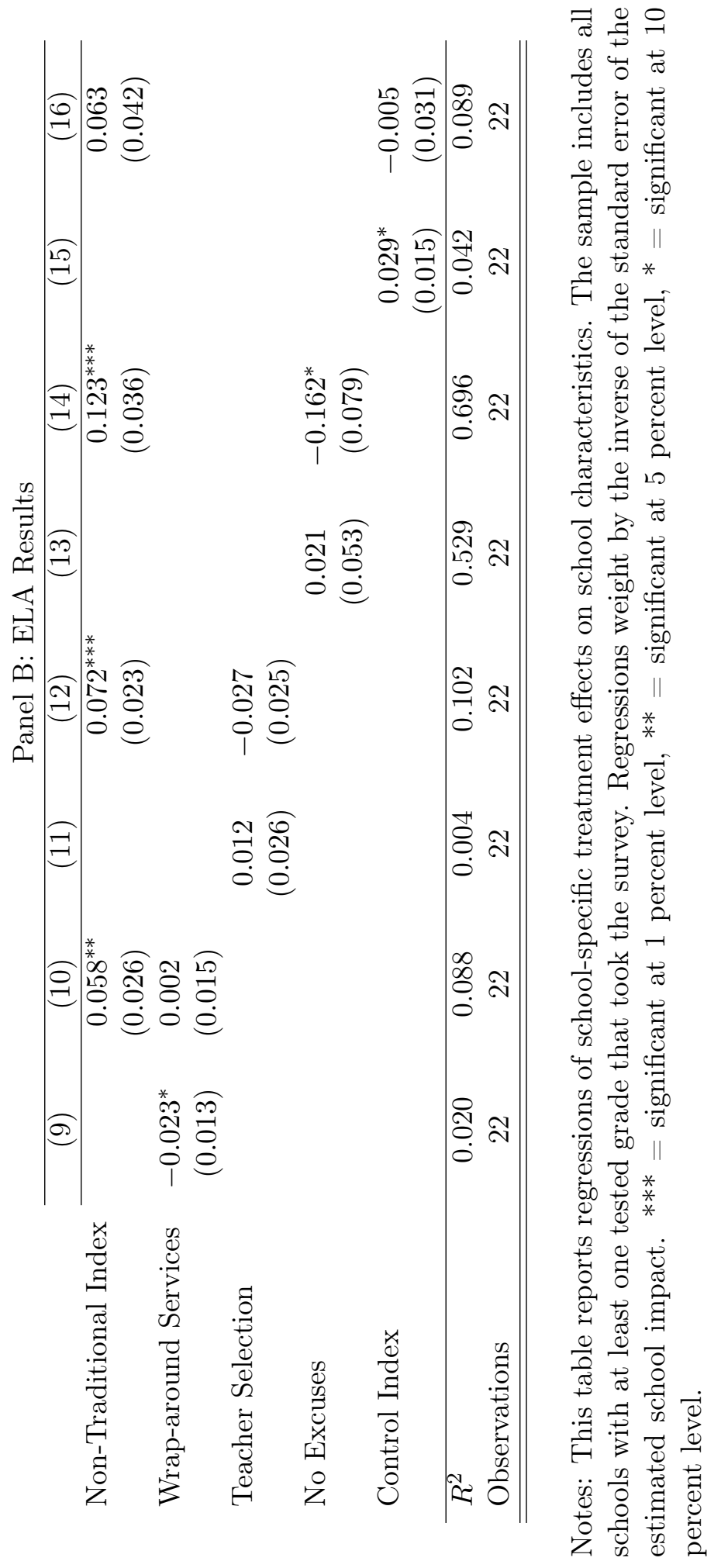

